IBAD Sosyal Bilimler Dergisi

IBAD Journal of Social Sciences

dergipark.org.tr/ibad

IBAD, 2021; (10): 72-95

DOI: $10.21733 /$ ibad. 848754

Özgün Araştırma / Original Article

\title{
Çalgi-Kimlik İnşasında Toplumsal Cinsiyetin Rolü ve Kayseri'de Akordeon Çalan Çerkez Kadınların Çalgı Seçim Süreçleri
}

\section{The Role of Gender in The Construction of Instrument-Identity and The Instrument Selection Processes of Circassian Women Playing Acordeons in Kayseri}

\author{
Yasemin Karataş ${ }^{1 *}$ \\ Turan Sağer ${ }^{2}$

\section{* Sorumlu yazar \\ Corresponding author}

${ }^{1}$ Arş. Gör., Adıyaman Üniversitesi, Türkiye Res. Assist., Adiyaman University, Turkey ykaratas@adiyaman.edu.tr ORCID ID 0000-0001-9148-1003

${ }^{2}$ Prof. Dr., Yıldız Teknik Üniversitesi, Türkiye Prof. Dr., Yildiz Technical University, Turkey tsager@yildiz.edu.tr

ORCID ID 0000-0002-1059-678X

Makale geliş tarihi / First received : 28.12.2020

Makale kabul tarihi / Accepted $\quad$ : 15.02.2021

\section{Bilgilendirme / Acknowledgement:}

\section{Yazarlar aşağıdaki bil gilendirmeleri yapmaktadırlar:}

1- Araştırma, birinci yazarın tezinden türetilmiş ve ikinci yazarın danışmanlığında gerçekleşmiştir.

2- Bu çalışma, Yıldız Teknik Üniversitesi, Sosyal Bilimler Enstitüsü, Sanat ve Tasarım Ana Sanat Dalı, Müzik ve Sahne Sanatları Doktora Programında tamamlanmakta olan “Çalgı-Kimlik İnşasında Toplumsal Cinsiyetin Rolü: Kayseri'de Akordeon Çalan Çerkez Kadınlar" başlıklı doktora tezinden hareketle oluşturulmuştur.

3- Makalenin yazarları arasında çıkar çatışması bulunmamaktadır.

4- Araştırma verileri 2020 yılı öncesinde toplanmıştır.

5- Bu makalede araştırma ve yayın etiğine uyulmuştur.

This article was checked by iThenticate. Similarity Index $10 \%$

\section{Atıf bilgisi / Citation:}

Karataş, Y., Sağer, T. (2021). Çalgı-kimlik inşasında toplumsal cinsiyetin rolü ve Kayseri'de akordeon çalan Çerkez kadınların çalgı seçim süreçleri. IBAD Sosyal Bilimler Dergisi, (10), 72-95. 


\section{ÖZ}

Çalg1-kimlik inşası sürecinde değinilen konulardan biri de çalgılara cinsiyetler atfedilmesi ve çalgıların cinsiyetleştirilmesidir. Farklı kültürlerde bazı çalgılar kadın çalgısı ya da erkek çalgısı olarak adlandırılmaktadır. Toplumsal cinsiyet algılarının büyük rol oynadığı bu durumda, toplumun değer yargıları ve kültürel özellikleri oldukça etkilidir ve çalgilara cinsiyetler atfedilmesi konusunun, toplumların kültürel özelliklerine göre oluştuğu ve geliştiği söylenebilir. $\mathrm{Bu}$ doğrultuda bireylerin çalg1 seçimleri de toplumsal cinsiyet algıları ve toplumsal cinsiyet rollerinden etkilenebilmektedir. Kadın çalgısı olarak adlandırılan ve kadınlıkla ilişkilendirilen çalgılar çoğunlukla kadınlar tarafından tercih edilirken, erkek çalgısı olarak adlandırılan ve erkeklikle ilişkilendirilen çalgılar ise çoğunlukla erkekler tarafından tercih edilebilmektedir. Araştırmada, akordeon çalan Çerkez kadınlarda bulunan toplumsal cinsiyet algılarının, çalgı seçiminde ne ölçüde rol oynadığı ve kadınların bu durumdan nasıl etkilendiklerini belirlemek amaçlanmıştır. Yapılan alan araştırmasıyla Kayseri'de bulunan ve akordeon çalan Çerkez kadınlar tespit edilip, 16 kadının çalgı seçimi süreçlerinde toplumsal cinsiyetin etkisinin olup olmadı̆̆ çalışılmıştır. Araştırma, nitel araştırma yöntemlerinden betimsel araştırma modeline uygun olarak gerçekleştirilmiş ve alan araştırmasına yer verilmiştir. Veri toplama aracı olarak yarı yapılandırılmış görüşme soruları geliştirilerek, akordeon çalan Çerkez kadınlara uygulanmıştır. Araştırmada görüşme tekniği kullanarak elde edilen veriler, betimsel analiz yönteminden yararlanılarak analiz edilmiştir. Elde edilen verilerden yola çıkıldığında kadın katılımcıların çalg1 seçimlerini toplumsal cinsiyet algılarından, toplumsal cinsiyet rollerinden, aile ve çevreden etkilenerek edinilmiş akıl yoluyla gerçekleştirdikleri, geçmişte ağırlıklı olarak kadınların çaldığı ve katılımcılara göre kadın çalgısı olarak adlandırılan bu çalgıyı kullanmayı tercih ettikleri sonuçlarına ulaşılmıştır.

\section{Anahtar kelimeler}

Toplumsal cinsiyet, çalgı kimliği, çalgı seçimi, akordeon çalan Çerkez kadınlar.

\section{ABSTRACT}

One of the issues addressed in the instrument-identity construction process is the attribution of genders to instruments and the genderization of instruments. Some instruments in different cultures are called as women's or men's instruments. In this situation where gender perceptions play a major role, the value judgments and cultural characteristics of the society are very influential and it can be said that the issue of attributing genders to instruments is formed and developed according to the cultural characteristics of societies. Accordingly, individuals' choice of instruments can also be affected by gender perceptions and gender roles. While the instruments that are associated with femininity and called the female instrument are mostly preferred by women, the instruments called the male instrument and associated with masculinity are mostly preferred by men. In the study, it was aimed to determine to what extent the gender perceptions of Circassian women playing accordion play a role in the selection of instruments and how women are affected by this situation. With the field research, Circassian women playing accordion in Kayseri were identified, and it was tried to determine whether gender affected the instrument selection processes of 16 women. The research was carried out in accordance with the descriptive research model, one of the qualitative research methods, and the field research was conducted. As a data collection tool, semi-structured interview questions were developed and applied to Circassian women playing accordion. The data obtained using the interview technique in the study were analyzed by using the descriptive analysis method. Based on the data obtained, it is observed that female participants made their musical instrument choices through the mind acquired by being influenced by gender perceptions, gender roles, family and environment and that women preferred to use this instrument as it was played mainly by women in the past and was called the female instrument according to the participants.

\section{Keywords}

Gender, instrument identity, instrument selection, Circassian women playing accordion. 


\section{Gíriş}

Cinsiyet kavramı, kadın ve erkekler arasındaki doğuştan kaynaklanan biyolojik, genetik ve fizyolojik farklılıkları içeren, kadın ve erkekler arasındaki biyolojik farklılıkları tanımlarken kullanılabilecek bir kavramdır. Toplumsal cinsiyet kavramı ise kadın ve erkeklere toplum tarafından atfedilen roller olarak tanımlanmaktadır. Toplumdan topluma, kültürden kültüre farklılık gösterebilen ve değişken bir durumdur. Konuyla ilgili olarak Üner; cinsiyeti, bireylerin kadın ve erkek olarak sahip oldukları genetik, fizyolojik ve biyolojik özellikleri olarak, toplumsal cinsiyet ise toplumun bu bireylere verdiği roller, görev ve sorumluluklar, toplumun bireyleri nasıl gördüğü, algıladığı ve beklentileri olarak tanımlamaktadır (2008, s. 6).

Cinsiyet ve toplumsal cinsiyet algıları birbirinden farklı olarak değerlendirilmektedir. Cinsiyetin fizyolojik ve biyolojik farklılıklar olarak kabul edildiği düşünüldügü̈nde, toplumsal cinsiyet bireylere toplum tarafından atfedilen özellikler olarak değerlendirilmektedir. Toplumsal cinsiyet bireylerin nasıl yaşamalarından, nasıl davranmaları gerektiğine kadar ve hatta seçimlerini dahi etkileyebilen bir durumdur. Bu doğrultuda bireylere toplumsal cinsiyet rolleri belirlenmektedir ve bu durum edinilmiş akıl yoluyla kuşaktan kuşağa aktarılmaktadır. Kız ve erkek çocukları hemcinslerinden etkilenerek, toplumun belirlediği bu rolleri kabullenirler ve uygularlar.

Toplumsal cinsiyet rolleri, kadınların daha çok ev içinde ve özel alanlarda, ev işleri eğitim gibi konularla ilgilenmesini ve bu konularda aktif olmasını sağlarken, erkeklerin ise kamusal alanda aktif olmasını, maddi kazanç sağlamasını ve güç gerektiren konularla ilgilenmesini sağlamaktadır. Bem, Martyna ve Watson'a (1976) göre; feminen roller ağırbaşlı, anlayışlı, başkalarının ihtiyaçlarına duyarlı, boyun eğen, cana yakın, çocukları seven, duygusal, gönül alan, kaba dil kullanmayan, kadınsı, merhametli, namuslu, sadık, sevecen, tatlı dilli gibi sıralanırken maskülen roller ise ailesine karşı sorumlu, baskın, duygularını açı̆ga vurmayan, erkeksi, güçlü, girişken, gözü pek, haksızlığa karşı tavır alan, hırslı, idealist, kendi ihtiyaçlarını savunan, kendine güvenen, kuralcı, katı, lider gibi davranan, mantıklı, otoriter şeklinde siralanmaktadır (Dökmen, 1999, s. 33'den aktaran Gelibolu ve Tanrıkulu, 2014, s. 245). Bu durum da toplum içerisinde, sosyal yaşamda kadınların erkeklere göre arka planda olmasına ve bazı sınırlılıklarla karşılaşmalarına neden olmuştur. Tüm alanlarda olduğu gibi müzik alanına da toplumsal cinsiyet rollerinin etkili olduğu ve bu durumun müzik alanına da yansıdığı görülmektedir.

Tarih boyunca kadınlar sosyal statü olarak erkeklerden daha geri planda kalmış olup ekonomiden akademik ortamlara kadar bu durum varlığını sürdürmüş ve müzik alanında da kadınların geri planda olduğu görülmüştür (Edvenson, 2017, s. 2). Kadınların performans alanından çalgı seçimlerine kadar toplumsal cinsiyet rolleri ve toplumsal cinsiyet algıları etkisini göstermiştir.

$\mathrm{Bu}$ durum kadınların müzikal yaşamlarında bazı kısıtlamalarla ve sınırlamalarla karşılaşmalarına neden olmuştur. Kadınların çalgı seçimleri, performans pratikleri, müzikal yaratıcılık durumları toplumsal cinsiyet rollerinden ve algılarından etkilenip, onların müzikal yaşamlarını olumsuz yönde etkileyebilmektedir. Bu doğrultuda Yunanistan'ın kırsal bölgelerinde, kadınların çalgı çalmalarının engellenmesi, bu bölgede vokal formların korunmasına neden olması örnek olarak gösterilebilir (Auerbagh, 2007, s. 222'den aktaran 
Yılmaz, 2010, s. 14). Çalgılarını kullanamayan kadın icracılar, müzikal yönelimlerini farklılaştırarak onlara uygun görülen şarkı söyleme faaliyetleriyle müzikal yaşantılarını devam ettirmektedirler.

Bazı kültürlerde ve toplumlarda kadınlar, erkekler için uygun olan çalgılar da bulunmaktadır. Toplum tarafından kadınların kadınlıkla ilişkilendirilen çalgıları kullanmayı tercih etmeleri, erkeklerin ise erkeklik ile ilişkilendirilen bu çalgıları kullanmayı tercih etmeleri beklenmektedir. Bu durum çalgıların cinsiyetleştirilmesine yol açabilmektedir. Böylece bireyler çalgılara atfedilmiş cinsiyetler doğrultusunda çalgı seçimlerini gerçekleştirebilmektedir.

16. yüzyılda yaşamış olan tarihçi Gelibolulu Mustafa Ali çalgıları sınıflandırırken erkek, dişi çalgılar olarak iki gruba ayırmış ve çalgıları cinsiyetleştirmiştir (Beşiroğlu ve Koçhan, 2007, s. 127). Tarihsel süreç incelendiğinde bu durumun geçmişten beri var olduğu görülmüş, toplumsal cinsiyet rolleri ve algılar çalgılara da aktarılmıştır. Böylece çalgı kimlik oluşum sürecinde bazı çalgıların kadınlık ya da erkeklik gibi cinsiyetlere sahip olmaları sağlanmıştır.

Yapılan araştırmalara göre; "tiz ses bölgesindeki yaylı ve üflemeli çalgılar kadınlıkla ilişkiliyken; pes ses bölgesindeki yaylı çalgılar, pirinç malzemeden yapılmış olan üflemeli çalgılar ve vurmalı çalgılar ise erkeklikle ilişkilidir" (Abeles ve Porter, 1978; Delzell ve Leppla, 1992; Griswold ve Chroback, 1981; Harrison ve O'Neill, 2000; Rife, Shnek, Lauby ve Lapidus, 2001'den aktaran Vickers, 2015, s. 8). Bu konuya örnek olarak Nort ve Hargreaves arp, çeng ve def gibi çalgıların kadınlıkla ilişkilendirilerek estetik olarak kadınlara uygun görüldüğünü, bunun aksine davul, bando-mızıka ve ağaçtan yapılan üflemeli çalgıların kadınların estetiğine uygun olmadığından kadınlıkla ilişkilendirilmediğini vurgulamaktadır (Ersoy, 2007, s. 25). Kadınlık ve erkekliğin gerektirdiği incelik, zariflik ve güç gibi birçok özelliğin benzer özellikleri taşıyan çalgılarla ilişkilendirildiği görülmektedir.

Ersoy Çak ney çalgısının Türk din musikisi icrasında erkekler tarafından üflendiğini, bu çalgının geleneksel icrasında kadınların yer almayışının çalgıya erkek kimliği kazandırdığını ve böylece çalgının hangi işlev için kullanıldığının cinsiyet algısını etkilediğini belirtmektedir (2017, 223'den aktaran Gündoğdu, 2019, 16). Günümüzde az da olsa kadın ney icracıları, öğreticileri bulunmakta ve çalgiların cinsiyetleştirilme durumu dönemden döneme toplumsal algılarla birlikte değişebilmektedir (Ersoy Çak, 2017, s. 224'den aktaran Gündoğdu, 2019, s. 16).

Yapılan araştırmalarda çalgıların insanlarla benzerlik gösteren özelliklere sahip olduğu ve cinsiyetlerle de ilişkili oldukları belirtilmektedir. Çalışmalarda çalgıların seslerinin kadın sesi erkek sesi gibi ince ve kalın olabilmesi, boyutlarının büyük ya da küçük olması gibi insanla ilişkilendirilebilen özelliklerinin bulunduğu belirtilmektedir. Çalgıların cinsiyetleştirilmesi de toplumsal cinsiyet rolleri ve algıları doğrultusunda şekillenerek ortaya çıkmaktadır.

Çalgı seçiminde sosyolojik, fizyolojik ve psikolojik açıdan bireylerin etkilenebileceği birçok faktör bulunmaktadır. Bunlardan biri de çalgıların cinsiyetleştirilmesi konusundaki toplumsal cinsiyet faktörüdür. Ayrıca kadınlara ve erkeklere atfedilen rollerde çalgı seçimini büyük ölçüde etkilemektedir. Çalgı seçimi sürecinde kadınların postürlerini bozmayacak çalgıları kullanmayı tercih etmeleri, erkeklerin fiziksel güç gerektirdiği düşünülen çalgıları seçmeleri bu süreci etkileyen durumlardan bazılarıdır.

Çalg1 tercihi sürecinde bireylerin çalgı seçimini etkileyebilecek birçok faktörün bulunduğunu bilimsel olarak açıklamaya çalışan Hallam, Rogers ve Creech cinsiyet eşitliğinin kabul gördüğü 
bir zamanda, çalgıların cinsiyetleştirilmesi ve çalgı tercihi konusunda birçok faktörün etkili olduğunu belirtmiş; bu faktörleri bireysel, sosyal ve çalgısal faktörler olarak üç ana başlık altında toplamıştır (2008, s. 15).

Çalgı tercihi yapan bireylerin bu süreçte kendilerine en uygun çalgıyı seçebilmeleri, ilerleyen müzikal yaşantıları açısından büyük önem taşımaktadır. Bu doğrultuda çalgı alanında başarılı olabilmek için uygun bir çalgı tercihi çok önemli görülmektedir (Graham, 2005, s. 1). Yapılan çalgı seçimi ile yaşam boyu müzikal başarıyı yakalamak ya da bu çalgının kullanılmasının devamlılığını sağlamak açısından çalgı seçiminde oldukça özenli davranılmalıdır.

MacKenzie tarafından konuyla ilgili çalgı seçiminde öğretmenlerin, ailenin, arkadaşların da rehberliğinin önemli olduğu belirtilmiştir (1991'den aktaran Bayley, 2000, s. 15). Conway tarafından, çalgıların karakteristik özelliklerinin çalgı seçimini etkileyen faktörlerden biri olduğu vurgulanmıştır. Ayrıca Conway çalgıların tınısı, boyutu, ses hacmi/yoğunluğu, orkestradaki rolü gibi etkenlerin, öğrencilerin çalgı seçimlerini etkilediğini vurgulamıştır (2000, s. 13).

Bu doğrultuda Kayseri'de akordeon çalan Çerkez kadınlarında çalgı seçimlerinin toplumsal cinsiyet, çalgı kimliği, toplumsal cinsiyet rolleri, edinilmiş akıl, kültür, aile, çevre ve sosyal yaşam gibi konulardan etkilendikleri düşünülmektedir. Kayseri'de yaşayan Çerkez toplumuna mensup kadınların akordeon çalma kültürüne sahip olmaları, geçmişte hemen hemen her kadının akordeon çaldığı bilinmektedir. Kadınların çalg1 seçimlerinin de hemcinslerinden etkilenerek gerçekleştirdikleri düşünülmektedir.

Peker yaptığı bir çalışmada Çerkez halkındaki kadınlar ve erkeklerin, toplumsal hayatın her alanında yan yana yer aldığını, gelenekçi bir halk olmalarına rağmen kadınlar ve erkekler arasına bir sınır bulunmadığını belirtmiştir $(2018$, s. 3). Çerkez toplumunda kadınlar ve erkekler her alanda yan yana yer almaktadır. Çerkezlerde kadına verilen önem oldukça büyüktür ve kadınlar yaşamın hiçbir alanında ikinci planda yer almamışlardır. Bu bağlamda kadınların akordeon çalmalarında ve istedikleri her ortamda icra etmelerinde bir sakınca görülmemiştir. Diğer toplumların aksine Çerkez toplumunda kadınlar özgürdürler ve ön planda yer alırlar. Bu durumda kadınların çalgılarını oldukça rahat bir şekilde icra etmelerine yol açmiştır.

Çerkez toplumunda müziğe, dansa olan ilgi oldukça büyüktür ve kültürlerinde önemli bir yeri bulunmaktadır. Kadın, erkek her birey bu faaliyet içerisinde rahatlıkla yer bulabilmektedir. Toplumlardaki cinsiyet algıları göz önünde bulundurulduğunda, Çerkez toplumunda kadınların da toplumsal alanda müzik ve dans gibi sanatsal faaliyetlerde oldukça aktif olarak yer aldıkları göz ardı edilemez. Diğer toplumlarla kıyaslandığında Çerkezlerde kadınlar toplumsal cinsiyet bağlamında oldukça özgür olabilmekte ve eğlencelerde kendilerine çalgısal alanda da yer bulabilmektedirler.

Kadın ve erkeğin birlikte yer aldığı müzik ve dans, Çerkez toplumunda önemli görülen kültürel aktivitelerdendir. Çerkez aileler, dansçı ve çalgı icracısı olarak ikiye ayrılıp, çalgı icrasını gerçekleştiren aileler, mızıka isimli akordeonu kullanarak müzik kültürünü gelecek nesillere aktarmaktadır (Erdal, 2019, s. 215). Mızıka Çerkez müziğinin çok sesli olarak gerçekleştirilmesini sağlayan bir akordeondur ve Çerkez toplumunda akordeonun taklit edilmesi üzerine çok sesli müziği icra etme geleneği oluşmuştur (Erdal, 2019, s. 215). Çerkez 
toplumunda bu çalgıyı çoğunlukla kadınlar çalmaktadır ve bu çalgı kadın çalgısı olarak adlandırılmaktadır.

Tok (2018, s. 22) yaptığı araştırmada Çerkezlerde kız çocuklarının müziğe karşı ilgilerinin ve yeteneklerinin olduğunu, 19. Yüzyılda müzikle sadece erkeklerin ilgilendiğini, Çerkezlerin milli çalgısı olan mızıkanın (pşine/garmon) hayatlarına girmesiyle, önceleri kız ve oğlan çocuklarının oyuncağı olarak kullanılan çalgının sonralarda geliştirilip kültürel bir boyut kazandırılarak kadınların da bu çalgıda ön plana çıkmaya başladığını vurgulamıştır.

Kadınların bir çalgıyla toplum içinde ön plana çıkıyor olması, Çerkez halkının toplumsal cinsiyet bağlamında kadınların sosyal yaşamda aktif olarak rol almalarına karşı olumlu yönde bir bakış açısına sahip olduklarını göstermektedir. Çerkez toplumunda kadınların bir müzik aleti çalması ve Çerkezlerde önem verilen bir çalgının çoğunlukla kadınlar tarafından çalınıyor olması kadınlara verilen önemi de ortaya koymaktadır.

Guçeva, 19. yüzyılda erkek mızıkacıların olmadığını, mızıkayı yalnızca kadınların çaldığını, akordeonun çalgı olarak geliştirilmesinden sonra Kafkas halklarında kadın akordeon icracı sayısının arttığını ve bunun bir meslek haline dönüştüğünü belirtmiştir (2005, s. 192-193'den aktaran Tok, 2018, s. 23). Harsiyev, erkeklerin bu çalgıyı 20. Yüzyılın başlarında kullanmaya başladıklarını belirtmiştir (Aktaran Tok, 2018, s. 23). Bu doğrultuda Çerkez halkına göre mızıka, belli bir zaman diliminde kadın çalgısı olarak kullanılmış ve yalnızca kadınlar tarafından çalınmıştır. Böylece kadınların çalgı seçimlerinde akordeonu tercih etmeleri kaçınılmazdır.

Mızıka/Akordeon kadınların fiziksel yapılarını ve estetik olarak görüntülerini bozmayacak bir çalgıdır. Çerkez toplumunda kadınların mızıka çalmaları estetik olarak da görünümleri bozmaması açısından önemlidir. Vurmalı çalgıların kullanımı kadınlara çok uygun olmadığından Çerkez kadınlar mızıka çalmayı daha çok tercih etmektedirler. Bu nedenle kadınlar için mızıka ve akordeon daha uygun bir çalgı olarak görünmektedir ve Çerkez toplumu tarafından kadın çalgısı olarak adlandırılmaktadır.

\section{Problem Cümlesi}

Kayseri'de akordeon çalan Çerkez kadınların toplumsal cinsiyet bağlamında çalgı seçimlerini etkileyen faktörler nelerdir?

\section{Araştırmanın Amacı ve Önemi}

$\mathrm{Bu}$ araştırmanın amacı, akordeon çalan Çerkez kadınların toplumsal cinsiyet bağlamında çalgı seçimlerini etkileyen faktörleri belirlemektir. Çalışma kapsamına akordeon çalan Çerkez kadınların toplumsal cinsiyet algıları, toplumsal cinsiyet rolleri, kültür, aile ve çevre gibi etkenlerden etkilenip etkilenmediğini tespit etmek amaçlanmıştır. Bu doğrultuda araştırmada, akordeon çalan kadınlara çalgı seçimlerini nasıl yaptıklarına ilişkin olarak sorular sorarak bu çalgıyı çalmaya nasıl karar verdikleri belirlenmeye çalışılmaktadır.

İç Anadolu bölgesinde kadınların akordeon çaldığı düşünüldüğünde kadınlar açısından olağan dışı olarak görülebilecek bir durum söz konusu olabilir. Bu doğrultuda, araştırma Kayseri'de akordeon çalan Çerkez kadınların çalgı seçimlerini içermesi ve ele alması bakımından önemli görülmektedir. 


\section{Araştırmanın Sınırlılıkları}

Araştırma, Kayseri'nin Pınarbaşı ilçesiyle ve akordeon çalan Çerkez kadınlarla sinırlandırılmıştır.

\section{YÖNTEM}

\section{Araştırmanın Modeli}

Araştırmada var olan durumu ortaya koymak ve durum saptaması yapmak adına nitel araştırma yöntemlerine başvurulmuş ve betimsel araştırma modeline yer verilmiştir. Kayseri'de akordeon çalan Çerkez kadınlarla etnografik bir çalışma olan alan araştırması yapılmıştır. Araştırmada tarihsel, kültürel ve sosyolojik art alan göz önünde bulundurularak katılımcılara daha önceden belirlenmiş olan yarı yapılandırılmış görüşme soruları sorulmuştur. Görüşme formunda katılımcıların çalgı seçimlerini nasıl yaptıkları, kullandıkları çalgının kimliği ve çalgı seçimi süreçlerinde toplumsal cinsiyet rollerinden etkilenip etkilenmedikleri konulu sorular bulunmaktadır.

\section{Evren ve Örneklem}

Araştırmanın evrenini Türkiye'de çalgı çalan kadınlar, örneklemini ise Kayseri'nin Pınarbaşı ilçesinde yaşayan ve akordeon çalan Çerkez kadınlar oluşturmaktadır.

Görüşme tekniği kullanılarak gerçekleştirilen araştırmada tamamı kadın katılımcı olan bireylerle derinlemesine görüşme yapılarak ayrıntılı bilgi toplanmaya çalışılmıştır. Katılımcların tamamının kadın olması, akordeon çalması ve Pınarbaşı Çerkezlerinden olması göz önünde bulundurulmuştur.

\section{Verilerin Toplanması ve Analizi}

Araştırmada toplumsal cinsiyet ve çalgı kimlik inşası konulu güncel ve tarihsel okumalar yapılıp, çalgı çalan kadınların performans pratiklerine ilişkin 9 soruluk yarı yapılandırılmış görüşme formu oluşturulmuştur. Oluşturulan yarı yapılandırılmış görüşme formu belirlenen kadın icracılara görüşme tekniği kullanılarak uygulanmış ve veriler elde edilmiştir. Kadın icracılarla yapılan ve karşılıklı görüşme tekniği (mülakat) kullanılarak elde edilen verilerin deşifresi yapılıp, yazılı olarak elektronik ortama aktarılmış, betimsel analiz yönteminden yararlanılarak analiz edilmiştir. Öncelikle yazılı metin haline getirilen sorulara kadın katılımcıların verdiği yanıtları içeren veriler kodlanmış, verilerden elde edilen kavramlara göre yapılan kodlamalar da temaları oluşturmuştur. Yapılan kodlama ve temaların sunumunda tablolardan yararlanılmıştır. Yıldırım ve Şimşek'e göre; "betimsel analiz, farklı veri toplama yöntemleriyle elde edilen verilerin belirlenen temalara göre özetlenmesi ve yorumlanması ile gerçekleşmekte olup, görüşme yapılan bireylerin görüşlerini yansıtabilmek adına görüşmecilerin belirttiği doğrudan alıntılara yer verilen ve temel amacı elde edilen bulguların okuyucuya özetlenip, yorumlanarak sunulması olan analiz türüdür" (2003'den aktaran Özdemir, 2010, s. 336).

\section{BULGULAR}

Araştırma bulguları kadın katılımcılarla yapılan görüşmelerden yola çıkılarak tablolaştırılmıştır. Tabloda frekans değerlerine ve yüzdelik değerlere yer verilmiştir. Kadın 
katılımcların isimleri belirtilmeden $\mathrm{K} 1, \mathrm{~K} 2, \mathrm{~K} 3 \ldots$ şeklindeki kodlar numaralandırılarak kullanılmıştır. Araştırma kapsamında görüş bildiren kadın katılımcıların belirttiği görüşlerden yola çıkılarak kod ve temalar oluşturulmuştur. Ardından kadın katılımcıların doğrudan görüşlerine yer verilmiştir. Bulgular bölümünde kadın katılımcılara ait demografik özelliklerin yanı sıra, toplumsal cinsiyet bağlamında değerlendirilen ve kadın katılımcıların çalgı seçimlerini etkileyen faktörlere, kullandıkları çalgının kimliği ve Çerkez kültüründeki yerine ilişkin verilere yer verilmiştir.

Tablo 1: Kadın Katılımciların Demografik Özellikleri

\begin{tabular}{|c|c|c|c|c|}
\hline Tema & Kod & İfade Bildiren Katılımcılar & f & $\%$ \\
\hline Cinsiyet & Kadın & $\begin{array}{l}\mathrm{K} 1, \mathrm{~K} 2, \mathrm{~K} 3, \mathrm{~K} 4, \mathrm{~K} 5, \mathrm{~K} 6, \mathrm{~K} 7, \mathrm{~K} 8, \mathrm{~K} 9, \\
\mathrm{~K} 10, \mathrm{~K} 11, \mathrm{~K} 12, \mathrm{~K} 13, \mathrm{~K} 14, \mathrm{~K} 15, \mathrm{~K} 16\end{array}$ & 16 & 100 \\
\hline \multirow{7}{*}{ Yaş } & $10-20$ & K16 & 1 & 6,25 \\
\hline & $21-30$ & K4 & 1 & 6,25 \\
\hline & $31-40$ & K12 & 1 & 6,25 \\
\hline & $41-50$ & K11 & 1 & 6,25 \\
\hline & $51-60$ & K1, K2, K6, K9, K10, K13, K14, K15 & 8 & 50 \\
\hline & $61-70$ & $\mathrm{~K} 3, \mathrm{~K} 7, \mathrm{~K} 8$ & 3 & 18,75 \\
\hline & $71-80$ & K5 & 1 & 6,25 \\
\hline $\begin{array}{c}\text { Doğum } \\
\text { yeri }\end{array}$ & $\begin{array}{c}\text { Kayseri } \\
\text { Pınarbaşı }\end{array}$ & $\begin{array}{l}\text { K1, K2, K3, K4, K5, K6, K7, K8, K9, } \\
\text { K10, K11, K12, K13, K14, K15, K16 }\end{array}$ & 16 & 100 \\
\hline \multirow{4}{*}{$\begin{array}{l}\text { Çerkez } \\
\text { boyu }\end{array}$} & Kabardey & $\begin{array}{l}\text { K3，K4，K5，K6，K7，K9，K10，K13, } \\
\text { K14, K15, K16 }\end{array}$ & 11 & 68,75 \\
\hline & Karaçay & K8 & 1 & 6,25 \\
\hline & Hatıkoy & $\mathrm{K} 2, \mathrm{~K} 11, \mathrm{~K} 12$ & 3 & 18,75 \\
\hline & Abaza & K1 & 1 & 6,25 \\
\hline \multirow{7}{*}{ Meslek } & Ev hanımı & K1, K3, K4, K7, K8, K9, K10, K11, K14 & 9 & 56,25 \\
\hline & Esnaf & $\mathrm{K} 2, \mathrm{~K} 12, \mathrm{~K} 13$ & 3 & 18,75 \\
\hline & Terzi & $\mathrm{K} 12, \mathrm{~K} 13$ & 2 & 12,5 \\
\hline & $\begin{array}{c}\text { Gida } \\
\text { mühendisi }\end{array}$ & K4 & 1 & 6,25 \\
\hline & Memur & K6 & 1 & 6,25 \\
\hline & Öğretmen & K15 & 1 & 6,25 \\
\hline & Öğrenci & K16 & 1 & 6,25 \\
\hline \multirow{5}{*}{$\begin{array}{l}\text { Öğrenim } \\
\text { durumu }\end{array}$} & İlkokul & $\mathrm{K} 1, \mathrm{~K} 5, \mathrm{~K} 7, \mathrm{~K} 8, \mathrm{~K} 10$ & 5 & 31,25 \\
\hline & Ortaokul & $\mathrm{K} 2, \mathrm{~K} 13, \mathrm{~K} 14, \mathrm{~K} 16$ & 4 & 25 \\
\hline & Lise & $\mathrm{K} 3, \mathrm{~K} 15$ & 2 & 12,5 \\
\hline & Üniversite & $\mathrm{K} 6, \mathrm{~K} 9, \mathrm{~K} 11, \mathrm{~K} 12$ & 4 & 25 \\
\hline & Lisansüstü & K4 & 1 & 6,25 \\
\hline
\end{tabular}

Tablo 1'de görüldüğü gibi tamamı kadın olan katılımcıların, 1'inin (\%6,25) 10-20 yaş aralığında, 1'inin $(\% 6,25)$ 21-30 yaş aralığında, 1'inin $(\% 6,25)$ 31-40 yaş aralığında, 1'inin (\%6,25) 41-50 yaş aralığında, 8'inin (\%50) 51-60 yaş aralığında, 3'ünün (\%18,75) 61-70 yaş aralığında ve 1'inin $(\% 6,25)$ ise $71-80$ yaş aralığında olduğu belirlenmiştir. Katılımcıların tamamının (\%100) Kayseri'nin Pınarbaşı ilçesinde doğdukları ve Çerkez Boyu olarak 11'inin $(\% 68,75)$ Kabardey, 1'inin $(\% 6,25)$ Karaçay, 3'ünün $(\% 18,75)$ Hatıkoy, 1'inin $(\% 6,25)$ Abaza 
sülalesine mensup oldukları görülmektedir. Katılımcıların 9'unun $(\% 56,25)$ ev hanımı, 3'ünün $(\% 18,75)$ esnaf, 2 'sinin $(\% 12,25)$ terzi, 1'inin $(\% 6,25)$ g1da mühendisi, 1'inin $(\% 6,25)$ memur, 1'inin $(\% 6,25)$ öğretmen ve 1'inin $(\% 6,25)$ de öğrenci olduğu belirlenmiştir. Ayrica katılımcların 5'inin $(\% 31,25)$ ilkokul, 4'ünün (\%25) ortaokul, 2'sinin $(\% 12,25)$ lise, $4^{\prime}$ ünün (\%25) üniversite ve 1'inin $(\% 6,25)$ lisansüstü mezunu oldukları belirlenmiştir.

Tablo 2: Çalgı Seçiminin Ne Zaman Yapıldığına İlişkin Kadın Katılımcı Görüşleri

\begin{tabular}{|c|c|c|c|c|}
\hline Tema & Kod & İfade Bildiren Katılımcılar & f & $\%$ \\
\hline $\begin{array}{c}\text { Okul } \\
\text { Öncesi } \\
\text { dönem }\end{array}$ & Çok küçük yaşta & K1, K6, K11, K15 & 4 & 25 \\
\hline $\begin{array}{l}\text { İlkokul } \\
\text { dönemi }\end{array}$ & 9-10 yaşlarımda & K5, K12, K13, K16 & 4 & 25 \\
\hline $\begin{array}{c}\text { Ortaokul } \\
\text { dönemi }\end{array}$ & 11 yaşımda & K8, K9, K13 & 3 & 18,75 \\
\hline \multirow{2}{*}{$\begin{array}{c}\text { Lise } \\
\text { dönemi }\end{array}$} & 15 yaşımda & K2, K7, K10, K14 & 4 & 25 \\
\hline & 17 yaşımda & K3 & 1 & 6,25 \\
\hline $\begin{array}{c}\text { Üniversite } \\
\text { dönemi }\end{array}$ & 24 yaşımda & $\mathrm{K} 4$ & 1 & 6,25 \\
\hline
\end{tabular}

Tablo 2'de çalgı seçimlerini yapan kadın katılımcıların okul öncesi dönem temasına göre; 4'ünün (\%25) çok küçük yaşlarda bu çalgıyı seçtiği, ilkokul dönemi temasına göre; 4'ünün (\%25) 9 ila 10 yaşlarında bu çalgıyı seçtiği, ortaokul dönemi temasına göre; 3'ünün (\%18,75) 11 yaşında bu çalgıyı seçtiği, lise dönemi temasına göre; 4'ünün (\%25) 15 yaşında ve 1'inin $(\% 6,25)$ ise 17 yaşında bu çalgıyı seçtiğini belirtmiş ve son olarak da üniversite dönemi temasına göre; katılımcların 1'inin $(\% 6,25) 24$ yaşında bu çalgıyı seçtiği belirlenmiştir. Bazı kadın katılımcı ifadeleri şu şekildedir:

K14; "15 yaşlarındayken. Dügünlere gittiğimde gizli gizli mızıkayı bulduğum zaman çalardım. Öyle öğrendim evde öğrenmedim ben. Öğrendikten sonra mızıkam oldu. Bir düğüne gitmiştik, mızıkacımız yorulmuştu. Bana "Bunu çalan bir bayan yok mu?" deyince, iyi kötü bir şey çıkartırım dedim, aldım çaldım. Ondan sonra meşhur bir mızıkacıydı düğünde çalan Sivas'tan gelmişti, erkekti. Adı Mahmut TÜFEKÇİ. Çok meşhur bir mızıkacı, mızıkasını bana hediye etti. Sen bunu çaldın, ben artık bunu gezdirmem diye yüz senelik mizıkasını bana hediye etti. Geri vermek istedim, almak istemedi. Bir sene sonra da adam vefat etti. Onun hatırası diye gezdiriyorum yani."

K9; “İlkokulu bitirdikten sonra. İlkokulu bitirdiğim senelerde seçtim. Dügüunlerde çalınan bir tek çalgımız var bizim, oda mızıka ve akordeondur. Benim annem de çalıyordu genetik yatkınlık olabilir. Anneannem de çalıyormuş. Aileden gelen bir kültür. Ben de sesini çok sevdim. Ondan sonra ailede genel yetenek olunca, abim de meraklıydı çünkü. Abim de üniversitede okuyordu o zaman bana mızıka aldı geldi, ben de evde gicırdata gıcirdata öğrendim."

K13; "11 yaşında seçtim. İlkokulu bitirdikten sonra. Küçük yaşlarda başladım yani. Abim çalıyordu, annem çalıyordu, halam çalıyordu. Onu çalmasam bir eksiklik hissederdim kendimde. Aile geleneği bizde yani." 
K6; “Köyde olduğum için başka bir seçeneğim yoktu. Ama acayipte bir ilgim vardı. Belki de dünyadaki tek çalgının akordeon olduğunu zannediyordum. Çok istiyordum kendi kendime de öğrendim birisi öğretmendi. Çok hatırlayamayacağım kadar küçük yaştaydım. Amcam söylüyor. Tabureleri elime alıp pşine diye çalarmışım. Çok hevesliydim."

Tablo 3: Çalgı Seçimi Sürecinde Toplumsal Cinsiyet Rollerinden Etkilenilmesine İlişkin Kadın Katılımoı Görüşleri

\begin{tabular}{ccccc}
\hline Tema & Kod & İfade Bildiren Katılımcılar & f & \% \\
\hline $\begin{array}{c}\text { Toplumsal } \\
\text { cinsiyet } \\
\text { rolleri } \\
\text { etkiler }\end{array}$ & $\begin{array}{c}\text { Evet. Çünkü bu } \\
\text { çalgı kadın } \\
\text { çalgısıdır }\end{array}$ & $\mathrm{K} 1, \mathrm{~K} 4, \mathrm{~K} 5, \mathrm{~K} 6, \mathrm{~K} 7, \mathrm{~K} 11, \mathrm{~K} 13$ & 7 & 43,75 \\
\hline $\begin{array}{c}\text { Toplumsal } \\
\text { cinsiyet } \\
\text { rolleri } \\
\text { etkilemez }\end{array}$ & $\begin{array}{c}\text { Hayır. Bu bizim } \\
\text { kültürümüzdür. }\end{array}$ & $\mathrm{K} 2, \mathrm{~K} 3, \mathrm{~K} 8, \mathrm{~K} 9, \mathrm{~K} 10, \mathrm{~K} 12, \mathrm{~K} 14, \mathrm{~K} 15, \mathrm{~K} 16$ & 9 & 56,25 \\
\hline
\end{tabular}

Tablo 3'de görüldüğü gibi, kadın katılımcıların bildirdiği toplumsal cinsiyet rolleri etkiler temasına göre; 7'si $(\% 43,75)$ evet yanıtını vermiş ve bu çalgının kadın çalgısı olduğunu belirtmiştir. Tabloda yer alan toplumsal cinsiyet rolleri etkilemez temasına göre; kadın katılımcıların 9'u $(\% 56,25)$ hayır yanıtını vererek bu çalgının kültürleri olduğunu ifade etmiştir. Kadın katılımcıların ifadelerinden bazıları şu şekildedir;

K13; "Kesinlikle etkilendim. Bu aslında kadın çalgısıdır çünkü. Şimdi biraz değişti ama aslen öyledir."

K7; “Evet. Erkekler hiç çalmazdı bu çalgıyı. Erkeklerin çaldığını bilmezdim o zaman. Kadınlar çalıyor diye biliyordum o zamanda hep öyle söylerdim kendi kendime. Kadınların çalması daha uygundur, daha güzeldir yani. Ben de bu yüzden seçtim. Çok meraklıydım, çok severdim."

K1; "Ben seviyordum açıkçası. Halam çalarken de oturur dinlerdim. Herhalde onu görüp heveslendim. Rol model oldu bana. Rahmetli babam hiç istemiyordu ama ben heveslendim, öğrendim, çaldım."

K3; "Hayır onu (toplumsal cinsiyet algısını) hiç düşünmedim. Benim hayalimde kırmızı çifte sıralı bir mızıka vardı hep. Tabii akordeonu da çok seviyoruz, insanın kanını harekete geçiriyor."

K14; "Hayır, kesinlikle hiç aklıma bile gelmedi. Ayrım yapmadım hiç. Çok seviyordum ben o yüzden seçtim."

K9; "Aslında toplumsal cinsiyet rolleri olarak şöyle oldu bizde. Ben annemden, anneannemden görerek çaldım ama benim erkek kardeşim de, abim de çalar. Aslında toplumsal cinsiyet yargısı yıkılıyor gibi olmuş olabilir o zamanlarda. Ya da toplumsal cinsiyet yargıları olmayabilir Çerkez halkında. Çünkü Çerkezlerde kadınlara çok önem verilir, çok değer verilir genç kızlara. Mızıka çalmakta çok değerli bir iş olarak görülür. Onlarda kadınlara ithaf edilmiştir. Yani kadın değerlidir, akordeon da çok değerli olduğu için Çerkezlerde değerli olan bir çalgıyı kadınların çalması daha hoş olacaktır. Bunu erkek 
yapar ya da kız yapar diye düşünülmemiştir. Kadınların akordeon çalması, kadına daha çok değer vermek için yapılmıştır. Ben böyle düşünüyorum."

Tablo 4: Akordeonun Çerkez Kültüründe Kadın Çalgısı Olmasına İlişkin Kadın Katılımcı Görüşleri

\begin{tabular}{|c|c|c|c|c|}
\hline Tema & Kod & İfade Bildiren Katılımcılar & f & $\%$ \\
\hline \multirow{3}{*}{$\begin{array}{c}\text { Çerkez } \\
\text { kültüründe } \\
\text { akordeon/pşine }\end{array}$} & $\begin{array}{l}\text { Akordeon } \\
\text { kadın } \\
\text { çalgısıdır }\end{array}$ & $\begin{array}{l}\mathrm{K} 1, \mathrm{~K} 2, \mathrm{~K} 3, \mathrm{~K} 4, \mathrm{~K} 5, \mathrm{~K} 7, \mathrm{~K} 8, \mathrm{~K} 10, \mathrm{~K} 13, \\
\mathrm{~K} 14, \mathrm{~K} 15, \mathrm{~K} 16\end{array}$ & 12 & 75 \\
\hline & $\begin{array}{l}\text { Pşine kadın } \\
\text { çalgısıdır }\end{array}$ & $\mathrm{K} 2, \mathrm{~K} 3$ & 2 & 12,50 \\
\hline & $\begin{array}{c}\text { Akordeon } \\
\text { kadın çalgısı } \\
\text { değildir } \\
\end{array}$ & $\mathrm{K} 1, \mathrm{~K} 2, \mathrm{~K} 3, \mathrm{~K} 6, \mathrm{~K} 9, \mathrm{~K} 11, \mathrm{~K} 12$ & 7 & 43,75 \\
\hline \multirow{4}{*}{$\begin{array}{c}\text { Çerkez } \\
\text { kültüründeki } \\
\text { değişim }\end{array}$} & $\begin{array}{l}\text { Günümüzde } \\
\text { erkekler } \\
\text { çalıyor }\end{array}$ & $\begin{array}{l}\text { K1, K2, K3, K4, K5, K8, K9, K11, K13, } \\
\text { K15 }\end{array}$ & 10 & 62,50 \\
\hline & $\begin{array}{c}\text { Kadınlardan } \\
\text { erkeklere geçti }\end{array}$ & $\mathrm{K} 2, \mathrm{~K} 3, \mathrm{~K} 4, \mathrm{~K} 5, \mathrm{~K} 6, \mathrm{~K} 8, \mathrm{~K} 9, \mathrm{~K} 15$ & 8 & 50 \\
\hline & $\begin{array}{l}\text { Yeniden } \\
\text { kadınlar } \\
\text { çalmaya } \\
\text { başladı }\end{array}$ & K2 & 1 & 6,25 \\
\hline & $\begin{array}{c}\text { Geçmişte hep } \\
\text { kadinlar } \\
\text { çalıyordu }\end{array}$ & $\begin{array}{l}\mathrm{K} 1, \mathrm{~K} 2, \mathrm{~K} 3, \mathrm{~K} 4, \mathrm{~K} 5, \mathrm{~K} 6, \mathrm{~K} 8, \mathrm{~K} 11, \mathrm{~K} 14, \\
\mathrm{~K} 15, \mathrm{~K} 16\end{array}$ & 11 & 68,75 \\
\hline
\end{tabular}

Tablo 4'de görüldüğü gibi, Çerkez kültüründe akordeon/pşine temasına göre; kadın katılımcıların 12'si (\%75) Çerkez Kültüründe akordeonun kadın çalgisı olduğunu, 2'si $(\% 12,50)$ Çerkez kültüründe pşinenin kadın çalgısı olduğunu ve 7 'si $(\% 43,75)$ ise akordeonun kadın çalgısı olmadığını ifade etmiştir. Tabloda yer alan Çerkez kültüründeki değişim temasına göre; katılımcı kadınların 10'u $(\% 62,50)$ akordeonu günümüzde erkeklerin kullandığını, 8'i (\%50) bu kültürün kadınlardan erkeklere geçtiğini, 1'i $(\% 6,25)$ yeniden kadınların çalmaya başladığını, 11'i $(\% 68,75)$ geçmişte hep kadınların çaldığını belirtmiştir. Kadın katılımcıların özgün ifadelerinden bazıları şu şekildedir:

K5; “Çerkezlerde önceden kadın çalgısıydı ama şimdi erkekler de çalıyor. Bana göre de kadın çalgısıydı. Sonradan erkekler öğrendi kadınlar da rahatladı. Sabaha kadar ayakta çalardık çünkü."

K1; "Evet kadın çalgısıdır. Önceden hep kadınlar çalardı zaten bu çalgıyı. Bir on, onbeş senedir çalıyor erkekler bu çalgıyı. Bizim zamanımızda çalan erkek çok azdı. Uzunyayla'da ya bir ya iki kişi vardı. Ben de kadın çalgısı olduğunu düşünüyorum."

K4; "Şu anda her ne kadar roller değişmiş olsa da akordeon çalımının daha zor olması, değişen zamanla kadınların şehirlere göç etmesiyle ki önceden köylerde sosyal hayat olmadığından kadınlar uğraşırdı akordeonla. Ama şehirlerde artık çok uğraşmıyorlar. Bu çalgının kadın çalgısı olduğunu düşünüyorum ama günümüzde kültürel değişimden dolayı erkekler de çalıyor. Bu çalgıyı kadın çalgısı olarak nitelendirebiliriz." 
K8; "Bizim zamanımızda kadın çalgısıydı. Aman erkek de çalar mı diyorduk. Ama şimdi hepsi eşitlendi çalıyorlar. Şimdi eski kadın mızıkacıların şeyi kalmadı. Gelse de olur gelmese de. Ama eskiden o toplumda bir araya gelindiği zaman. Kadın akordeoncuyu mutlaka getirirlerdi."

Tablo 5: Akordeon Çalarken Fiziksel Olarak Yaşanan Zorluklara İlişkin Kadın Katılımcı Görüşleri

\begin{tabular}{|c|c|c|c|c|}
\hline Tema & Kod & İfade Bildiren Katılımcılar & f & $\%$ \\
\hline \multirow{4}{*}{$\begin{array}{c}\text { İcracının } \\
\text { yaşadığı } \\
\text { fiziksel } \\
\text { zorluklar }\end{array}$} & Çok yorucu & $\begin{array}{l}\text { K2, K3, K4, K5, K6, K7, K8, K9, K10, } \\
\text { K11, K12, K13, K14, K15, K16 }\end{array}$ & 15 & 93,75 \\
\hline & $\begin{array}{c}\text { Severek yapınca } \\
\text { yorucu değil }\end{array}$ & K1, K3, K5, K8, K15 & 5 & 31,25 \\
\hline & $\begin{array}{l}\text { Kadın gücü } \\
\text { yetersiz } \\
\text { kalabiliyor }\end{array}$ & K2, K6, K9, K11, K12, K13, K14, K15 & 8 & 50 \\
\hline & $\begin{array}{c}\text { Sakatliklar } \\
\text { oluyor }\end{array}$ & K2, K4, K7, K9, K13, K15 & 6 & 37,50 \\
\hline \multirow{3}{*}{$\begin{array}{l}\text { Çalgının } \\
\text { neden } \\
\text { olduğu } \\
\text { fiziksel } \\
\text { zorluklar }\end{array}$} & Çalg1 ağır & $\begin{array}{l}\text { K1, K3, K4, K5, K6, K7, K8, K10, K11, } \\
\text { K13, K14, K15, K16 }\end{array}$ & 13 & 81,25 \\
\hline & Körük zorluyor & $\begin{array}{l}\text { K2, K4，K6，K7，K10，K12，K14，K15, } \\
\text { K16 }\end{array}$ & 9 & 56,25 \\
\hline & $\begin{array}{l}\text { Ayakta çalmak } \\
\text { yorucu }\end{array}$ & K2, K5, K7, K8, K15 & 5 & 31,25 \\
\hline $\begin{array}{l}\text { Çalma } \\
\text { süresi }\end{array}$ & $\begin{array}{l}\text { Sabaha kadar } \\
\text { çalmak yorucu }\end{array}$ & K2, K3, K5, K7, K8, K9, K10, K13, K14 & 9 & 56,25 \\
\hline
\end{tabular}

Tablo 5'de akordeon çalan Çerkez kadınlar fiziksel olarak yaşadığı zorlukları belirtilmektedir. İcracıların yaşadığı fiziksel zorluk temasına göre; kadın katılımcıların 15'i $(\% 93,75)$ çok yorucu olduğunu, 5'i $(\% 31,25)$ severek yapılınca yorucu olmadığını, 8'i $(\% 50)$ kadın gücünün yetersiz kalabildiğini ve 6'sı da $(\% 37,50)$ sakatlıkların olabildiğini belirtmiştir. Çalgının neden olduğu fiziksel zorluklar temasına göre; kadın katılımcıların 13'ü $(\% 81,25)$ çalgının ağır olduğunu, 9'u $(\% 56,25)$ körüğün zorladığını 5'i $(\% 31,25)$ ayakta çalmanın yorucu olduğunu belirtmiştir. Çalma süresi temasına göre; kadın katılımcıların 9'u $(\% 56,25)$ sabaha kadar bu çalgıyı çalmalarının yorucu olduğunu belirtmiştir. Kadın katılımcıların özgün ifadelerinden bazıları şu şekildedir:

K12; “Tabii, çok yorucu. Özellikle sol fonksiyon çok zor. Kadın olduğumuz için çok zorlaniyoruz."

K3; “Tabii ki. Yorulurduk, çalgı ağırdı, uzun süre çalardık ama aşkla yapardık. O bizim kültürümüz. Bunu severek isteyerek yapınca hiç yorgunluk hissetmezsiniz. Ben ölecek bile olsam akordeon çalarken kültür şehidi oldum derim. Ben bunun için yaşıyorum."

K8; “Tabii ki. Sürekli çaldığımız için sırtım çok ağrırdı. Bir de şu parmağım (sağ elin başparmağı) çok ağrırdı. Sürekli parmağımla desteklediğim için. Ama tabii gençken yorulmuyordum. Şimdi iki kişi oynayınca yoruluyorum. Sabaha kadar oturmazdık bile. Ayakta çalardık ayıp olur diye hep ayakta çalardım sabaha kadar. Bir genç kız olarak oturarak çalmak o topluma saygısızlıktı. Ama şimdi yaşlandık oturup çalıyoruz. Tavlıdere diye bir Abaza köyü var. Orada 20 gün her akşamüzeri mızıkamı alırdım, bütün toplum 
toplanırdı, gece yarısına kadar dügün yaptırırdım. Misafir gelince toplanır dügün yapılırdı. Dügün deyince gelin damada gerek yoktur bizde. Misafire değer verildiği için eğlence yapılırdı. Gelen misafirleri görmeye haçeş evine herkes gelirdi. Orda eğlence yapardık."

K7; “Çok zorlanıyordum. İnan ki şu sırtımdan dökülüyordu ter. Avcunu tutsan dolardı yani. Öyle de beklerdik. O büyükler izin vermeden dışarı çıamazdık. Şimdi su getirip su içiyorlar ortamda. Kimi gidiyor, kimi geliyor. Kimin orda olduğu belli değil. Biz onlardan, yaşlılardan izin alır öyle çıkardık. 5 dakika dinlenir geri gelirdik. Birazcık geciktik mi hemen birini gönderirlerdi çabuk gelin diye. Ceza verirlerdi. Bir şeyler isterlerdi. Çay, yemek bir şeyler verirdin, muhabbet olsun diye. $\mathrm{O}$ zamanın gençlerine yani şimdiki benim yaşımdakilere soracaksın. Zorlanıyordum güç istiyor bu çalgı. Kulunç oldum hatta. Kollarımda yırtılma var inan sol kolum şişiyordu çalarken. 20-25 kilo ağırlığındaki akordeon halbuki benimki hafifti ama öyle de olan başka yerlere gittiğimizde çaldığımız akordeonlar vardı. Şimdi bizler akordeon çalıyoruz da şimdikiler mızıkayı çalamaz. Mızıka çok zor. Mesela aynı tuştan körüğü çekince başka bir ses, itince başka bir ses çıkar. Kafe çalarken körüğü uzun çekiyorsun, onu geri itmek çok zorluyor."

K5; “Tabii... Yoruluyordu insan ama yorgunluk nedir bilmiyorduk. Düğün yapılıyor diyerek seve seve çalıyorduk. Aşk vardı. Mesela mızıkayı çalarken teee küçüklükte ilk o teyzemin kızı gelip de o oynadıkları çaldıkları kafeleri şeşenleri çalardı. Film şeridi gibi gözümün önünden geçer bunlar. Hepsinin bir anısı var. Falanın dügünü̈nde bunu çalmıştık, filanın düğününde bunu çalmıştık diye aklına geliyor insanın. Eskiden çalmak çok zordu. Şimdi iki kola askı takılıyor. Önceden bir teneke koyarlardı yere, üstüne basarak ayakta çalınırdı. Çok yorucuydu. Şimdi misafir yolcu ederken biraz şuraya oturayım diyoruz. Eskiden sabaha kadar çalardık ama yorulsak da yorulduk demezdik."

K14; “Ayy onu söyleyeyim hemen. Bunu çalmayan bilmez. Mızıkacılar nazlanıyor diyorlar Çerkez kızları için. Öyle değil ama çok yorucu bir şey. Gerçekten çok yorucu. O körügü açıp kapatmak yoruyor insanı. Dügüunlerde çalanların yorgunluklarını hissediyordum o zamanlar. Demek ki diyorum şimdi anlıyorum mızıkacılar nazlı değil, çok yoruldukları için dinlenmek için çalmak istemiyorlardı. Çok yorucu bir şey."

K13; “Tabii. Baya bir güç gerektiriyor yoruluyorsunuz ister istemez. Ağır bir çalgı. Uzun süre çalınca yorucu oluyor. Gece dügün başlardı neredeyse sabahlara kadar çalardık. Artık sabah kollar şişmiş, kaldıramaz hale gelirdi. Bir dügün yapılırdı sabahlara kadar."

Tablo 6: Çalgı Seçimlerini Yaparken Etkilendikleri Kişilere İlişkin Kadın Katılımcı Görüşleri

\begin{tabular}{cllcc}
\hline \multirow{2}{*}{ Tema } & \multicolumn{1}{c}{ Kod } & Ifade Bildiren Katılımcilar & \multirow{2}{*}{$\mathbf{f}$} & \multirow{2}{*}{$\%$} \\
\hline \multirow{7}{*}{ Aile } & Anne & $\mathrm{K} 4, \mathrm{~K} 9, \mathrm{~K} 12, \mathrm{~K} 13, \mathrm{~K} 14, \mathrm{~K} 15$ & 6 & 37,5 \\
\cline { 2 - 5 } & Anneanne & $\mathrm{K} 9$ & 1 & 6,25 \\
\cline { 2 - 5 } & Babaanne & $\mathrm{K} 15$ & 1 & 6,25 \\
\cline { 2 - 5 } & Abla & $\mathrm{K} 10, \mathrm{~K} 15$ & 2 & 12,5 \\
\cline { 2 - 5 } & Teyze & $\mathrm{K} 11$ & 6 & 6,25 \\
\cline { 2 - 5 } & Hala & $\mathrm{K} 1, \mathrm{~K} 3, \mathrm{~K} 6, \mathrm{~K} 10, \mathrm{~K} 13, \mathrm{~K} 14$ & 2 & 12,5 \\
\cline { 2 - 5 } & Yenge & $\mathrm{K} 3, \mathrm{~K} 8$ & 3 & 18,75 \\
\cline { 2 - 5 } & Kuzen & $\mathrm{K} 5, \mathrm{~K} 7, \mathrm{~K} 13$ & 2 & 12,5 \\
\hline
\end{tabular}




\begin{tabular}{|c|c|c|c|c|}
\hline \multirow{3}{*}{ Çevre } & $\begin{array}{l}\text { Aile dostu } \\
\text { (kadın) }\end{array}$ & K2 & 1 & 6,25 \\
\hline & Komşu (kadın) & K3 & 1 & 6,25 \\
\hline & $\begin{array}{l}\text { Tanınmayan } \\
\text { birçok insan } \\
\text { (kadın) }\end{array}$ & $\mathrm{K} 6, \mathrm{~K} 7, \mathrm{~K} 9, \mathrm{~K} 13, \mathrm{~K} 16$ & 5 & 31,25 \\
\hline
\end{tabular}

Tablo 6'da akordeon çalan Çerkez kadınların çalgı seçimlerini yaparken etkilendikleri kişilere ilişkin verilere yer verilmiştir. Aile temasına göre; kadın katılımcıların 6'sı $(\% 37,5)$ anne, 1'i $(\% 6,25)$ anneanne, 1'i $(\% 6,25)$ babaanne, 2'si $(\% 12,5)$ abla, 1'i $(\% 6,25)$ teyze, 6's1 $(\% 37,5)$ hala, 2'si $(\% 12,5)$ yenge, 3 'ü $(\% 18,75)$ kuzen ve 2 'si $(\% 12,5)$ ağabey yanıtını vermiştir. Çevre temasına göre; katılımcı kadınların 1'i $(\% 6,25)$ aile dostu bir kadın, 1'i $(\% 6,25)$ komşu bir kadın ve 5'i $(\% 31,25)$ tanınmayan birçok kadından etkilendiklerini belirtmişlerdir. Kadın katılımcılarla gerçekleştirilen görüşmelerdeki bazı özgün ifadeler şu şekildedir:

K12; “Annem çok güzel çalıyordu. Ondan etkilendim. Ben de derslerimi bitirdikten sonra merak ettiğim için, aa bu tuştan nasıl ses çıkıyor, aaa bu nasıl açılıp kapanıyor derken ezgi çıkmaya başlayınca, ben de çalmaya başladım."

K5; “Teyzemin kızından etkilendim. Teyzemin kızı çalıyordu. Oğlanlar geliyor, onları oynatıyordu, çalıyordu. Ona heveslenerek öğrendik işte. Bunu eskiden daha çok kadınlar çalardı. Görümcelerimin üçü de çalar, onların küçük kızı çok güzel çalar. O sonradan bir mızıka gönderdi bana Almanya' dan. Çok güzeldi o mızıka onu da çaldım."

K15; “Tabii ki evet. Babaannem, annem, ablam çalardı mızıka. Ben de onlardan etkilendim. Bu bizim kültürümüz zaten. Evimizde hep mızıka çalınırdı."

K10; "Halam çalard1, ablam çalard1. Ablamdan sonra bana kaldı akordeon. Etkileniliyor insan ister istemez. Benim kızım da benden etkilendi mesela. Ben çalıyordum, o da çalmak istedi."

K13; “Annem ve halam çalıyordu. Abim çalıyordu. Sülalede amcamın kızları vardı. Çok güzel giyinirlerdi. Çok güzellerdi. Bir de akordeonu alıp çaldıkları zaman ben hayran kalırdım. Çevreden de etkileniliyor mutlaka. Ben çevremden de çok etkilendim. Kendime rol model aldığım mızıkacı ablalar vardı. Onlara heveslendiğim için evet benimde çalmam lazım dedim. Ben etkilendim şahsen."

K3; "Halamdan ve bir komşumuz vardı ondan etkilendim ben. Komşumuzun bir mızıkası vardı, o aklını yitirmişti. Mızıkasına bakmak için ölümü göze alır gider evlerinde otururdum. Sırf onu uzaktan görmek için. Büyüklerimden etkilendim, sülalede beğendiğim halalar vardı onlardan etkilendim. Abimin eşi çok ustaydı ondan da etkilendim."

K7; "Yakınlarımdan... Amcamın kızından etkilendim o mızıkacıydı, çalıyordu. Ama çevremde de çoktu mızıka çalan kadın. Onlardan da etkilendim." 
Tablo 7: Akordeon Çalan Çerkez Kadınların Çalgı Seçimlerini Kültürel Etkilerden ve Akordeonun Kadın Çalgısı Olmasından Dolayı Gerçekleştirmelerine İlişkin Kadın Katılımoı Görüşleri

\begin{tabular}{|c|c|c|c|c|}
\hline Tema & Kod & İfade Bildiren Katılımcılar & f & $\%$ \\
\hline \multirow{4}{*}{$\begin{array}{c}\text { Kültürel } \\
\text { etkiler }\end{array}$} & $\begin{array}{l}\text { Kültürümüzde } \\
\text { akordeon } \\
\text { kadın } \\
\text { çalgısıdır }\end{array}$ & $\begin{array}{l}\mathrm{K} 1, \mathrm{~K} 2, \mathrm{~K} 3, \mathrm{~K} 4, \mathrm{~K} 5, \mathrm{~K} 7, \mathrm{~K} 8, \mathrm{~K} 9, \mathrm{~K} 10, \mathrm{~K} 11, \\
\mathrm{~K} 13, \mathrm{~K} 16\end{array}$ & 12 & 75 \\
\hline & $\begin{array}{c}\text { Akordeon } \\
\text { yalnızca kadın } \\
\text { çalgısı değildir }\end{array}$ & $\mathrm{K} 3, \mathrm{~K} 4, \mathrm{~K} 5, \mathrm{~K} 6, \mathrm{~K} 12$ & 5 & 31,25 \\
\hline & $\begin{array}{c}\text { Akordeon } \\
\text { kültürümüzde } \\
\text { çok önemlidir }\end{array}$ & $\begin{array}{l}\mathrm{K} 1, \mathrm{~K} 2, \mathrm{~K} 3, \mathrm{~K} 4, \mathrm{~K} 5, \mathrm{~K} 6, \mathrm{~K} 7, \mathrm{~K} 8, \mathrm{~K} 9, \mathrm{~K} 10, \\
\mathrm{~K} 11, \mathrm{~K} 12, \mathrm{~K} 13, \mathrm{~K} 14, \mathrm{~K} 15, \mathrm{~K} 16\end{array}$ & 16 & 100 \\
\hline & $\begin{array}{c}\text { Dilden sonra } \\
\text { gelen ikinci } \\
\text { aktarım } \\
\text { aracıdır }\end{array}$ & $\mathrm{K} 2, \mathrm{~K} 4, \mathrm{~K} 9, \mathrm{~K} 15$ & 4 & 25 \\
\hline $\begin{array}{c}\text { Bireysel } \\
\text { etkiler }\end{array}$ & İlgim vard 1 & K1, K3, K4, K5, K6, K7, K9, K10, K12 & 9 & 56,25 \\
\hline
\end{tabular}

Tablo 7'de görüldügü gibi, akordeon çalan Çerkez kadınların çalg1 seçimlerini kültürel etkilerden dolayı gerçekleştirmelerine ve akordeonun kadın çalgısı olarak adlandırılmasına yönelik olarak belirttikleri ifadeler yer almaktadır. Kültürel etkiler temasına göre; kadın katılımcıların 12'si (\%75) kültürümüzde akordeon kadın çalgısıdır, 5'i $(\% 31,25)$ akordeon yalnızca kadın çalgısı değildir, 16'sı (\%100) akordeon kültürümüzde çok önemlidir ve 4'ü (\%25) dilden sonra gelen ikinci aktarım aracıdır yanıtını vermiştir. Bireysel etkiler temasına göre; kadın katılımcıların 9'u $(\% 56,25)$ ise ilgim vardı cevabını vermiştir. Kadın katılımcıların ifadelerinden bazıları şu şekildedir:

K10; "Evet öyle aslında kadın çalgısı olduğu için çaldım. Çünkü bu çalgıyı hep kadınlar çalardı. Sevdiğimiz için çaldık. Kültürümüzün parçasıdır akordeon."

K5; “Evet, kültürden dolayı ve hep kadınlar çaldığı için . Çok severek çaldık. Düğünlere gideriz diye heves ederek çaldık. Çerkezlerde mızıkacı çok önemliydi. Çok kıymetliydi o zaman. Akrabaların bir dügünü olursa gidilirdi düğüne, yabancıya bile özel olarak gelir götürürlerdi mızıkacıyı. Eskiden kızlar çalardı hep mızıkayı. Şimdi erkekler de çalıyor. Sadece kadın çalgısı değil artık. Eskisi kadar çalmıyor kızlar mızıkayı bıraktılar artık."

K15; "Çalgı seçimini kültürel etkilerden dolayı yaptım. Akordeon biz Çerkezler için dilden sonra gelen en önemli araçlardandır."

K11; “ Tabii ki kültürel etkilerden dolayı seçtim. Kadın çalgısı olarak bilinir bu.”

K16; “Akordeonu eskiden hep kadınların çaldığını biliyorum. Annem babam öğrettiler. Bir de akordeon bizim kültürümüzde çok önemli."

K6; “Hayır. Kadın çalgısı olduğu için değil de, ilgiyle alakalı. Müzik kulağım vardı ama sadece Çerkez müziklerine karşı kulağım var benim oda ilginçtir. Asla farklı bir müzikte 
çalamıorum. Yani ezgilerimiz hep kulağımda ezbere biliyorum hepsini. Oda öyle parmaklarıma dökülüyor. \%90 ilgi."

K3; "Benim isteğim normal değildi olağan üstüydü. Çocukken rüyalarıma girerdi. Hatta çocukken bunu kullanırlardı. Bir yakınımız vardı bana hep hadi bir soğuk su getir sana mızıka alacağım derdi. Onun da bir ablası vardı. Mızıkaları kalmıştı duruyordu. Ben köyü sora sora buldum onları. Abiniz mızıkanızı bana verdi götürmeye geldim demişim. İki hanım oturuyordu böyle kraliçe gibi. Adete göre büyük olan sedirde oturuyor, küçük alçak olan yerde sedirde. Katina sen misin yavrum dediler. Babam Katina derdi bana. Şimdi o çok ağır maalesef götüremezsin güzelim dediler. Sen git güzelce biz arkandan göndeririz dediler. $\mathrm{Ne}$ bir güldüler, ne dalga geçtiler. Sonra ben eve dönmeye çalıştım. Allah'ım gidiyorum gidiyorum sıcakta evde bir uzak anlatamam. Beklemeye başladım bir taşın üzerinde getiren olmadı. Getirmediler. O derece aşıktım."

Tablo 8: Akordeonun Çerkez Halkına ve Kadın Katılımcılara Göre Ne Iffade Ettiğine İlişkin Görüşler

\begin{tabular}{|c|c|c|c|c|}
\hline Tema & Kod & İfade Bildiren Katılımcılar & $\mathbf{f}$ & $\%$ \\
\hline \multirow{4}{*}{$\begin{array}{l}\text { Kültürel } \\
\text { sembol/konum }\end{array}$} & $\begin{array}{l}\text { Kültürümüzün } \\
\text { önemli bir } \\
\text { parçası }\end{array}$ & $\begin{array}{l}\text { K1, K2, K3, K4, K5, K7, K8, K9, } \\
\text { K10, K11, K12, K13, K14, K15, } \\
\text { K16 }\end{array}$ & 15 & 93,75 \\
\hline & $\begin{array}{l}\text { Kültürel aktarım } \\
\text { aracı }\end{array}$ & $\begin{array}{l}\text { K1，K2，K4，K5，K8，K10，K11， } \\
\text { K12, K13 }\end{array}$ & 9 & 56,25 \\
\hline & $\begin{array}{c}\text { Özgürlüğüu ifade } \\
\text { aracı }\end{array}$ & K1, K3, K6, K15 & 4 & 25 \\
\hline & Birliktelik sağlar & K12 & 1 & 6,25 \\
\hline \multirow{3}{*}{$\begin{array}{l}\text { Çalgının } \\
\text { kullanım alanı }\end{array}$} & $\begin{array}{l}\text { Düğünlerimizin } \\
\text { temel çalg1sı }\end{array}$ & $\begin{array}{l}\text { K2, K3, K5, K6, K7, K8, K9, K14, } \\
\text { K16 }\end{array}$ & 9 & 56,25 \\
\hline & $\begin{array}{l}\text { Yaşamın her } \\
\text { alanında } \\
\text { kullanılır }\end{array}$ & $\begin{array}{l}\text { K1, K2, K5, K6, K7, K8, K9, K10, } \\
\text { K12, K14, K15 }\end{array}$ & 11 & 68,75 \\
\hline & $\begin{array}{l}\text { Yas günlerinde } \\
\text { kullanılmaz }\end{array}$ & $\mathrm{K} 2, \mathrm{~K} 3, \mathrm{~K} 6, \mathrm{~K} 9, \mathrm{~K} 11$ & 5 & 31,25 \\
\hline
\end{tabular}

Tablo 8'de akordeonun Çerkez halkına ve kadın katılımcılara göre ne ifade ettiğine ilişkin veriler yer almaktadır. Kültürel sembol/konum temasına göre; kadın katılımcıların 15'i $(\% 93,75)$ akordeonunun kültürlerinin bir parçası olduğunu, 9'u $(\% 56,25)$ akordeonun kültürel aktarım aracı olduğunu, 4'ü (\%25) akordeonun özgürlüğü ifadece aracı olduğunu ve 1'i $(\% 6,25)$ ise akordeonun birliktelik sağladığını belirtmiştir. Tablodaki çalgının kullanım alanı temasına göre; kadın katılımcıların 9'u $(\% 56,25)$ akordeonun düğünlerin temel çalgısı olduğunu, 11'i $(\% 68,75)$ akordeonun yaşamın her alanında kullanıldığını ve 5'i $(\% 31,25)$ ise akordeonun yas günlerinde kullanılmadığını belirtmiştir. Kadın katılımcıların ifadelerinden bazıları şöyledir:

K4; “Her ne kadar biz burada doğmuş ve büyümüş olsak da, sürgün ve göçün gerçekleşmesinden sonra kendi kültürümüzü başkalarına, farklı milletlere ifade etmede kullandığımız en etkili araç müziktir. Bu konuda da bizim müziğimize en uygun olan çalgı 
da akordeondur. Kültürün yaşatılması, tanıtılması ve kendimizi ifade etmek açısından önemli bir araç olduğunu düşünüyorum."

K2; "Akordeon Çerkezlerde olmazsa olmazlardan birisidir. Nasıl Türklerde davul zurna önemliyse bizim için de akordeon, mızıka çok önemli. Biz onsuz yaşayamayız. Şimdi internette görüyorum bizimkilerde hep oyun çalgı, oyun çalgı ne taşkınlık var ne başka bir şey var. Akordeon olmazsa olmaz yani. Bu çalgı hep oyuna dansa yönlendirir. Geçmişten bugüne ağıtlar söylenir. Onu çalarken bile her çalınan melodinin bir anısı vardır. Hem söyleyip hem çalıyorlar. Her parçanın ayrı bir anlamı yaşanmışlı̆̆ı var. O yüzden biz Çerkezler için çok önemlidir. O olmazsa biz yaşayamazdık."

K3; “Mızıka dur deyince durmaz, çal deyince de çalmaz. Mızıka nerdeyse kutsallığımızdır. 70 'lerde öyle hatırlıyorum. Dügünü̈ bastılar durun dediler. Bütün gençler o mızıkanın önüne durdu. O dur deyince durmaz, çal deyince de çalınmaz, mızıkalar durmasın dediler. Biz ne yapıyoruz ki burada kültürümüzü yaşatıyoruz dediler. Sen dur dedi bizim gençler. Onlarda biraz utandı geri geri gitti. Birbirlerine bir şeyler söylediler, gittiler."

K8; "Geleneksel çalgımızdır akordeon bizim. Bu çalgıyla daha çok ağıtlar yakıldı ve çalındı. Her yerde kullanıyoruz. Ağıtta onunla, eğlencede onunla. Bizim için vazgeçilmez bir alet."

K9; “Olmazsa olmaz gibi bir şey. Bizim dügünlerimizin en büyük enstrümanı. Başta o olmadan olmuyor. Benim için de öyle sesi de, kendisi de çok güzel geliyor. Yani akordeon sesini duyunca içi hoplamayan bir Çerkez yoktur. Bizleri etkiliyor. Çocukluktan beri duya duya benimsiyoruz herhalde. Ama şu an Türk dügüunlerinde de oluyor aynı şey. Demek ki insanlar içinde bulundukları toplumun adetlerini benimseyebiliyorlar. Çocukluğumuzda bizim toplumumuz kendi içindeydi, kapalıydı, dışarıya açık değildi. Türk toplumuna açık değildik. Sürekli Çerkez Çerkez’le evlenirdi, Çerkez düğünü yapılırdı. Şimdi artık Çerkez Türk'le evleniyor. Yarısı Çerkez yarısı Türk oluyor düğünlerin. Ailelerin kiminde Çerkez gelini var kiminde Çerkez damat var. Öyle olunca iki kültürü de birlikte yürütme olayına giriyoruz. Gayette iyi yürütüyoruz."

K6; “Özgürlüğü ifade ediyor. Baka bir şey değil yani. Acayip özgür hissediyoruz kendimizi gençken. Evlendikten sonra biraz farklılaşıyor tabii. Özgürlüğü ifade ediyor başka bir şey koyamıyorum yerine. Aslında Çerkezlerin olmazsa olmazındandır. Her alanda, her zaman kullanılır. Bir düğün olmasına gerek yok toplantıda bile yer alır. Su gibi bir şeydir yani, ekmek gibi bir şeydir. Bir tek yas günlerinde ele alınmaz."

Tablo 9: Akordeon Çalan Kadınlara Toplumun Bakış Açısının Nasıl Olduğuna İlişkin Kadın Katılımoı Görüşleri

\begin{tabular}{|c|c|c|c|c|}
\hline Tema & Kod & İfade Bildiren Katılımcılar & $\mathbf{f}$ & $\%$ \\
\hline \multirow{3}{*}{$\begin{array}{c}\text { Toplumun } \\
\text { akordeon } \\
\text { çalan kadina } \\
\text { olan bakış } \\
\text { açısı }\end{array}$} & Sayg1 duyulur & $\begin{array}{l}\mathrm{K} 1, \mathrm{~K} 2, \mathrm{~K} 3, \mathrm{~K} 4, \mathrm{~K} 5, \mathrm{~K} 6, \mathrm{~K} 7, \mathrm{~K} 8, \mathrm{~K} 9, \\
\mathrm{~K} 10, \mathrm{~K} 11, \mathrm{~K} 12, \mathrm{~K} 13, \mathrm{~K} 14, \mathrm{~K} 15, \mathrm{~K} 16\end{array}$ & 16 & 100 \\
\hline & Değer verilir & $\begin{array}{l}\mathrm{K} 1, \mathrm{~K} 2, \mathrm{~K} 3, \mathrm{~K} 5, \mathrm{~K} 6, \mathrm{~K} 7, \mathrm{~K} 8, \mathrm{~K} 9, \\
\mathrm{~K} 10, \mathrm{~K} 11, \mathrm{~K} 12, \mathrm{~K} 13, \mathrm{~K} 14, \mathrm{~K} 15\end{array}$ & 14 & 87,5 \\
\hline & Özel ilgi vardır & $\begin{array}{l}\mathrm{K} 1, \mathrm{~K} 2, \mathrm{~K} 3, \mathrm{~K} 6, \mathrm{~K} 7, \mathrm{~K} 8, \mathrm{~K} 9, \mathrm{~K} 10, \\
\mathrm{~K} 11, \mathrm{~K} 13, \mathrm{~K} 14, \mathrm{~K} 16\end{array}$ & 12 & 75 \\
\hline
\end{tabular}




\begin{tabular}{|c|c|c|c|c|}
\hline \multirow{2}{*}{$\begin{array}{l}\text { Günümüzdeki } \\
\text { kadın } \\
\text { icracılara olan } \\
\text { bakış açısı }\end{array}$} & $\begin{array}{c}\text { Günümüzdeki } \\
\text { kadın icracılar } \\
\text { erkeklerden daha } \\
\text { kıymetlidir }\end{array}$ & K2, K4, K6, K8, K9, K10, K14, K16 & 8 & 50 \\
\hline & $\begin{array}{l}\text { Kadınlar çalınca } \\
\text { daha çok mutlu } \\
\text { olurlar }\end{array}$ & $\begin{array}{l}\text { K1, K2, K4, K6, K8, K9, K10, K14, } \\
\text { K16 }\end{array}$ & 9 & 56,25 \\
\hline
\end{tabular}

Tablo 9'da akordeon çalan kadınlara olan toplumun bakış açısına ilişkin veriler yer almaktadır. Tabloda yer alan toplumun akordeon çalan kadına olan bakış açısı temasına göre; kadın katılımcıların 16'sı (\%100) saygı duyulduğunu, 14'ü $(\% 87,5)$ değer verildiğini ve 12 'si (\%75) ise özel ilginin olduğunu belirtmiştir. Tablo 9'da yer alan günümüzdeki kadın icracılara olan bakış açısı temasına göre; kadın katılımcıların 8'i (\%50) günümüzdeki kadın icracıların erkeklerden daha kıymetli olduğunu ve 9'u $(\% 56,25)$ toplumun kadınların akordeon çalmasıyla mutlu olduklarını belirtmişlerdir. Kadın katılımcıların ifade ettiği görüşlerden bazıları şu şekildedir:

K3; "Ben bir düğüne gitmiştim. Dinletiler olur ya hani, sıra geceleri gibi oturturlar, kadına çok değer verirler seni başköşeye oturturlar. Yaşça bile senden daha büyük biri dahi gelse sayg1 gösterir. Konser gibi düşünün dinlemeye geliyorlar yani. Ben elli iki, elli altı parça biliyordum. Çok eskilere dayanan parçalar. Ağıtlar vardı, Sarıkamış'a yapılan ağıtlar vardı, kaybettiklerimiz vardı, gözyaşı vardı. Hiç kimse eğlence için orada değildi. Ağlayanlar gördüm. Ölümlü yollar düşünebiliyor musunuz? Neyse mızıkayı kapattım kapatınca kendin koyamazsın fırlar mızıkayı birisi elinden alır geri geri çekilir. Thamade dediğimiz grubun bir büyügü vardır. Grup adına çok güzel bir konuşma, seni onurlandıracak bir konuşma yapar. Orada herkesin dikkatini çeken şu oldu. O konuşması gereken thamadenin sigara vardı elinde. Külü baya uzamıştı tablası vardı, işaret ettiler külü dökmemişsin diye. Dedi ki dikkatini dağıtır mıyım? Tam karşımda oturuyordu böyle parmağımla vururken falan acaba dikkatini dağıtır mıyım diye dökmedim dedi. Yemin ederim dokunamadım alçı gibi elim kaldı dedi. Çok saygı gösteriyordu herkes."

K8; "Çok saygı duyulur. En yaşlıları bile gelir, tebrik eder, teşekkür eder. Güzel bir konuşma yapar. Öyle bırakılır düğün. O toplanan grupta çaldığımda mesela thamade derler bizimkiler o gelir. Teşekkür eder ellerine, sağlık der. Öyle bırakırım. Yoksa öyle bırakıp çıkma yok. Zor bir meslekti ama seve seve yapardık."

K6; “Ooo hem de nasıl. Ultra saygı duyulurdu. Kesinlikle daha bir saygind. Tabii bu durum kırsal kesimde böyleydi. Şu an şehirde akordeon çalan kadın sayısı çok az, çok çok az, görmüyorum nerdeyse ama kesinlikle daha saygın bir yeri vardı. Dediğim gibi thamadeden sonra liderden sonra gelen ikinci kişi akordeoncuydu. Yani özel olarak zaten kizlar hep evden alınırdı. Öyle durumlarda hep akordeoncu için özel olarak önceden haber gönderilir. Ondan sonra gidip alınır. Farklı bir yerdedir akordeoncu. Pşinavo."

K2; “Bakış açısı çok güzeldir. Saygı duyulur ve el üstünde tutulur akordeon çalan kadınlar. Bir de şimdi eskisi kadar kalmadığı için daha da önemli görüyorlar. Kadınlar çalınca daha çok mutlu oluyorlar."

K9; “Tabii ki saygı duyulur. Sevilir. Diğer hanımlar gıpta ederler ay keşke ben de çalabilseydim diye, ilgi duyuyorlar yani. Mesela yaşı küçük dahi olsa biz de şey vardır 
büyük varsa kesinlikle onun baş tarafına oturulmaz ama genç kızsa kadınsa ne kadar büyük olursa olsun yerini ona verir. Akordeon çalan küçük bir kıza da aynı saygı gösterilir başköşede oturtulur. Hatta şimdilerde kadın akordeoncu az olduğundan daha çok seviliyor."

Tablo 10: Akordeonu Ağırlıklı Olarak Kimlerin Çaldığg ve Bu Kültürü Ağırlıklı Olarak Kimlerin Aktardığına İlişkin Kadın Katılımoı Görüşleri

\begin{tabular}{|c|c|c|c|c|}
\hline Tema & Kod & İfade Bildiren Katılımcılar & $\mathbf{f}$ & $\%$ \\
\hline \multirow{3}{*}{$\begin{array}{c}\text { Çalgıyı } \\
\text { kullananlar }\end{array}$} & $\begin{array}{l}\text { Geçmişte } \\
\text { kadınlar }\end{array}$ & $\begin{array}{l}\mathrm{K} 1, \mathrm{~K} 2, \mathrm{~K} 3, \mathrm{~K} 4, \mathrm{~K} 5, \mathrm{~K} 7, \mathrm{~K} 8, \mathrm{~K} 9, \mathrm{~K} 10, \mathrm{~K} 11, \\
\mathrm{~K} 12, \mathrm{~K} 13, \mathrm{~K} 14, \mathrm{~K} 15\end{array}$ & 14 & 93,33 \\
\hline & $\begin{array}{l}\text { Günümüzde } \\
\text { erkekler }\end{array}$ & $\begin{array}{l}\mathrm{K} 1, \mathrm{~K} 2, \mathrm{~K} 3, \mathrm{~K} 4, \mathrm{~K} 5, \mathrm{~K} 7, \mathrm{~K} 8, \mathrm{~K} 9, \mathrm{~K} 10, \mathrm{~K} 11, \\
\mathrm{~K} 12, \mathrm{~K} 13, \mathrm{~K} 14, \mathrm{~K} 15\end{array}$ & 14 & 93,33 \\
\hline & Kadınlar & $\mathrm{K} 2, \mathrm{~K} 3, \mathrm{~K} 6, \mathrm{~K} 11, \mathrm{~K} 13, \mathrm{~K} 14$ & 6 & 20 \\
\hline \multirow{3}{*}{$\begin{array}{l}\text { Kültürü } \\
\text { aktaranlar }\end{array}$} & $\begin{array}{l}\text { Geçmişte } \\
\text { kadınlar }\end{array}$ & $\begin{array}{l}\mathrm{K} 1, \mathrm{~K} 2, \mathrm{~K} 3, \mathrm{~K} 4, \mathrm{~K} 5, \mathrm{~K} 7, \mathrm{~K} 8, \mathrm{~K} 9, \mathrm{~K} 10, \mathrm{~K} 11, \\
\mathrm{~K} 12, \mathrm{~K} 13, \mathrm{~K} 14, \mathrm{~K} 15\end{array}$ & 14 & 93,33 \\
\hline & $\begin{array}{l}\text { Günümüzde } \\
\text { erkekler }\end{array}$ & $\begin{array}{l}\mathrm{K} 1, \mathrm{~K} 2, \mathrm{~K} 3, \mathrm{~K} 4, \mathrm{~K} 5, \mathrm{~K} 7, \mathrm{~K} 8, \mathrm{~K} 9, \mathrm{~K} 10, \mathrm{~K} 11, \\
\mathrm{~K} 12, \mathrm{~K} 13, \mathrm{~K} 14, \mathrm{~K} 15\end{array}$ & 14 & 93,33 \\
\hline & Kadınlar & K2, K3, K6, K11, K13, K14 & 6 & 20 \\
\hline \multirow{2}{*}{$\begin{array}{l}\text { Çalg1 } \\
\text { değişimi }\end{array}$} & $\begin{array}{c}\text { Mızıkayı } \\
\text { kadınlar çalar }\end{array}$ & $\mathrm{K} 3, \mathrm{~K} 13$ & 2 & 13,33 \\
\hline & $\begin{array}{l}\text { Akordeonu } \\
\text { erkekler çalar }\end{array}$ & K13 & 1 & 6,66 \\
\hline
\end{tabular}

Tablo 10'da görüldüğü gibi, akordeonu ağırlıklı olarak kimlerin çaldığına ve bu kültürü kimlerin aktardığına ilişkin olarak katılımcı görüşleri yer almaktadır. Çalgıyı kullananlar temasına göre; katılımcı kadınların 14'ü $(\% 93,33)$ geçmişte kadınlar, 14'ü $(\% 93,33)$ günümüzde erkekler, 6’sı (\%20) ise kadınlar yanıtını vermiştir. Kültürü aktaranlar temasına göre; kadın katılımcıların 14'ü $(\% 93,33)$ geçmişte kadınlar, 14'ü $(\% 93,33)$ günümüzde erkekler, 6'sı (\%20) ise kadınlar yanıtını vermiştir. Tablodaki çalgı değişimi temasına göre ise kadın katılımcıların 2'si $(\% 13,33)$ mızıkayı kadınların çaldığını ve 1'i $(\% 6,66)$ ise akordeonu erkeklerin çaldığını belirtmiştir. Katılımcı kadınların bildirdiği ifadelerden bazıları şu şekildedir:

K5; “Kadınlar daha çok kullanırdı eskiden. Şimdi erkekler kullanıyor, kadınlar çalmıyor pek. Kültürü aktaran da eskiden kadınlardı, şimdi erkekler."

K9; "Zamanına bağlı aslında bizim zamanımızdan önce tüm kadınlar çalardı. Hiç erkek yoktu. Benim zamanımda erkeklerle beraber çalmaya başladık. Şimdide erkekler daha çok çalıyor. Kadınlarda da bir şeyde az olunca rağbet olmaz ya kızlar da heveslenmiyor artık herhalde. Sanki erkeklerin çalması gereken bir aletmiş gibi görüyorlar onlar da birazcık."

K7; “Eskiden kadınlar çok kullanırdı, erkekler tek tük çalardı. Şimdi kadınlar tek tük çalıyor, yaşlı kadınlar çalıyor daha çok. Eskiden kültürü aktaran da kadınlardı, şimdi erkekler aktarıyor. Sürdüren şu anda erkekler.

K11; “Kadınlar önceden çok çaldılar. Benim neslimle birlikte erkekler de çoğalmaya başladı. Şimdi de erkeler daha yoğunlukta çalıyorlar. Bir dönem bıraktı kadınlar ama şimdi tekrar bi 
merak başladı. Çalmak istiyorlar yine. Aktarma konusuna gelirsek derneklerde erkekler aktarıyor toplum içerisinde de kadınlar."

K13; “Kadınlar aktarır kültürü. Ama erkeklere geçti şimdi. Geçmişte kadınlardı, günümüzde erkekler. Aslında kültürümüzde mızıka vardı, akordeon değil. Sonradan akordeon oldu. 1950 yıllarından sonra Balkanlardan gelen ikinci Çerkez göçüyle oraya yerleşen Çerkezler buraya gelirken yanlarında akordeon da getirdi. Öylece akordeon çalınmaya başladı. Aslında kadınlarda var hala çalan ve aktaran ama eskiden nerdeyse bütün kızlar çalardı şimdi az kaldı çok göremiyoruz. Erkekler daha rahat çalıyor herhalde."

\section{SONUÇ ve ÖNERILER}

Birçok toplumda kadınların geri planda kaldığı düşünüldügünde ataerkil bir yapıya sahip olan Çerkez toplumunda da kadınların ikinci planda yer alması beklenebilmektedir. Ancak Çerkez toplumunda kadının yeri ve önemi oldukça büyüktür. Bu doğrultuda toplumsal cinsiyet rolleri ve kalıplaşmış yargılar düşünüldüğünde Çerkez toplumu, kadını ön planda tutacak şekilde davranışlar sergilemektedir. Araştırma bulgularından da anlaşılacağı gibi kadınların akordeon çalıyor olması ve akordeonun kadınlara atfedilen bir çalgı olması bu durumu destekler niteliktedir.

Ataerkil bir toplum olan Çerkez toplumunda kadınların aktif bir biçimde çalgı icra etmeleri, çalgı çalmaları konusunda desteklenmeleri ve çalgı seçimlerini rahatlıkla gerçekleştirmeleri onların toplumsal cinsiyet bağlamında olumsuzluklarla karşılaşmadıklarının bir göstergesidir. Ayrıca araştırma kapsamında Çerkez kadınların çalgı icra etme ve çalgı seçimi konusunda geri planda kalmadıkları da ortaya çıkmaktadır.

Akordeon çalan kadınların kültürel bellekle paralel bir şekilde çalg1 seçimlerini gerçekleştirdikleri düşünüldüğünde, yıllardır paylaştıkları deneyimler ve toplumsal cinsiyet rolleri çalgı seçimlerinde büyük bir rol oynamaktadır. Akordeonun kadınlar tarafından kullanılıyor olması da Çerkez toplumu tarafından akordeonun kadın çalgısı olarak adlandırılmasına ve bu çalgının cinsiyetleştirilmesine yol açmaktadır. Çerkez toplumunda akordeon kadınlıkla ilişkilendirilen bir çalgı olarak kabul görmektedir.

Araştırma bulgularından yola çıkıldığında Çerkez toplumunun kadın icracıya olan bakış açısı, kadınların toplum içerisindeki var olma şekli, Çerkez toplumundaki toplumsal cinsiyet rolleri, kadın icracıların performans pratikleri ve çalgı seçim süreçlerinin birbiriyle bağlantılı olduğu görülmektedir. Çerkez halkının kadına verdiği değerden yola çıkılarak, çalgı seçimlerini gerçekleştirdikleri yaştan, etkilendikleri kişilere kadar kadın icracıların desteklendiği ve kadınları olumsuz yönde etkileyebilecek toplumsal cinsiyet kalıp yargılarının bulunmadığı ortaya çıkmıştır.

Çerkez kadınlar çalgı seçimlerini gerçekleştirirken edinilmiş akıl yoluyla hemcinslerinden etkilenmiş ve seçimlerini gerçekleştirmişlerdir. Ayrıca çalgilara atfedilen cinsiyet kimlikleri ve kodları da bireylerin çalgı seçimlerini etkilemektedir. Bu doğrultuda Çerkez toplumunda akordeonun kadın çalgısı olarak adlandırılması çoğunlukla kadınlar tarafından kullanılıyor olmasinı da desteklemektedir.

Akordeonun Çerkez kültüründe önemli bir kültürel aktarım aracı olması ve bu çalgının özellikle kadınlar tarafından kullanılıyor olması, akordeonun kadın çalgısı olarak 
adlandırılmasına yol açmıştır. Araştırmada toplumsal cinsiyet algıları doğrultusunda akordeon çalan kadınların çalgı seçimlerini çok küçük yaşlarda ve çevrelerindeki kadın icracılardan etkilenerek yaptıkları sonucuna varılmıştır. Kadınların ağırlıklı olarak kullandığı bu çalgının kadınlar tarafından da tercih ediliyor olması kaçınılmazdır.

Kadın katılımcıların çoğu çalgı seçimlerini kültürel etkilerden dolayı gerçekleştirdiklerini belirtseler de, akordeonu kadınların kullanması Çerkez kültürünün bir parçasıdır. Çerkez kültüründe kadınların akordeon çalması, dikiş dikmesi, yemek yapması ve çocuklara bakması gibi kadın meziyetleri arasında yer almaktadır. Bu doğrultuda çalgı seçimlerinin toplumsal cinsiyet algıları doğrultusunda gerçekleştirildiği ve toplumsal cinsiyet rolleriyle ilişkilendirilen kadınların akordeon çalması görevinin diğer kadınları da etkilediği görülmektedir. Kültürel özellikler nesilden nesile bu yolla aktarılmaktadır.

Akordeonun Çerkez kültüründe kadın çalgısı olduğu akordeon icra eden kadınlar tarafından doğrulanmıştır. Fakat Çerkez kültürünün değişime uğraması, Çerkez toplumunun asimile olması akordeonu yalnızca kadın çalgısı olmaktan ziyade her iki cinsiyetten bireylerin kullanabileceği bir çalgıya dönüştürmüştür. Fakat bu durum Çerkez kültüründeki akordeonun kadın çalgısı olduğu algısını değiştirememiştir. Geçmişte akordeon çalmayan kadın hemen hemen yokken, akordeon çalan erkeklerin sayısı parmakla gösterilecek kadar azmış. Kültürel olarak akordeonun kadın çalgısı şeklinde adlandırılması ve kadınlıkla ilişkilendirilmesi Çerkezlerde bulunan toplumsal cinsiyet algıları ile örtüşmektedir. Çerkez kültüründen yola çıkılarak da akordeonun çalgı kimliği değerlendirilirse kadınlıkla ilişkilendirilen, kadınlara yakışan ve kadınlar için uygun görülen bir çalgı olduğu söylenebilmektedir. Çerkez toplumun kuralları ve sosyokültürel yapıları doğrultusunda kadına yakışan bir çalgı olan akordeon kadınlığı çağrıştırmaktadır. Çerkez kültüründe asil ve çok değerli bir alet olan akordeon, kadınlara da aynı oranda verilen değerle ilişkilendirilerek, ikisini de aynı konuma koymaktadır. Ayrıca akordeon, kadınların asaletini bozmamakla birlikte onları toplum içerisinde daha da üst konumlara taşımaktadır.

Akordeonda yaşanan fiziksel zorluklar kadınların sakatlıklar yaşamasında, akordeon icrası gerçekleştirirken zorlanmalarına ve yorulmalarına neden olmaktadır. Güç gerektiren bu çalgı kadınlardan ziyade erkekler tarafından daha rahat kullanılmaktadır. Bu çalgının kadınlar tarafından bırakılmasının ve eskisi kadar yaygın olarak kullanılmamasının nedenlerinden birisi de bu olabilir. Kadınların akordeon çalarken zorlanmaları akordeon çalgısını yavaş yavaş bırakmalarına neden olmuştur. Erkeklerin fiziksel olan avantajları bu çalgıyı rahatlıkla çalmalarında büyük etkendir.

Araştırma kapsamında aile ve çevre rolünün çalg1 seçiminde oldukça etkili olduğu düşünülmektedir. Bunu toplumsal cinsiyet bağlamında değerlendirecek olursak, çevrelerinde ve ailelerinde kadınların akordeon çaldığını gören kız çocukları ve kadınlar, toplumsal cinsiyet rolleri gereği bunun kadınlar tarafından gerçekleştirilebilecek bir durum olduğunu düşünerek, bu çalgıyı kullanmayı tercih etmektedirler. Edinilmiş akıl yoluyla ailelerindeki ve çevrelerindeki kadınların davranışlarından etkilenen bireyler, çalgı olarak akordeonu seçmeyi tercih etmektedir. Bu durum akordeonun kadınlar tarafından kullanılmasına ve kadın çalgısı olarak adlandırılmasına neden olmaktadır. 
Akordeonun Çerkez kültüründe kadın çalgısı olarak bilinmesi, sosyokültürel özelliklerden kaynaklanmaktadır. Toplumun kültürel yapısını oluşturan özellikler içerisinde yer alan bazı durumlar, kadınları da toplumsal cinsiyet rolleri doğrultusunda akordeon çalmaya yöneltmiştir. Çerkez kültüründe akordeonun kadınlıkla ilişkilendirilmesi ve kadın çalgısı olarak kullanılması kültürün özellikleri içerisinde yer almaktadır. Bu doğrultuda kadınların akordeon seçimi ile kültürü nesilden nesile aktarmaya çalıştıkları görülmektedir.

Çerkez kültüründe akordeon dilden sonra gelen en önemli kültürel aktarım araçlarındandır. Yaşamın hemen hemen her alanında kullanılmakla birlikte, Çerkezlerin kendilerini ifade etme aracı olarak kullanılmaktadır. Çerkez toplumu ve kadınlar için yaşamlarında oldukça önemli bir yere sahiptir. Bu durumu toplumsal cinsiyet bağlamında değerlendirecek olursak akordeonu kadınların çalması toplum içerisinde kadınlara verilen değeri ortaya çıkarmaktadır. En değerli varlıklardan birinin kadınlara atfedilmesi, kadının toplumdaki önemini ortaya çıkarmakla birlikte, yerini de yüceltmektedir. Bu doğrultuda Çerkez toplumunda bu kadar önem verilen bir çalgının kadınlar tarafından tercih edilmesi oldukça doğal karşılanmaktadır. Kadınlar çalgı seçimlerini gerçekleştirirken çevreden ve kültürden etkilenmektedirler.

Akordeon çalan kadınlara karşı toplum saygılı bir tavır sergilemektedir. Ataerkil bir toplum olan Çerkez toplumunda kadınlara değer verilmesi toplumsal cinsiyet bağlamında oldukça önemli bir davranıştır. Kadınların toplum içerisinde yüceltilmeleri ve el üstünde tutulmaları Çerkez toplumunda öncelikli davranışlarındandır. Bu doğrultuda akordeon çalan kadınlara ise ayrıca özel bir ilgi vardır. Akordeon çalan kadınlar el üstünde tutulur ve toplum içerisinde akordeon çalan bir kadın varsa thamadeden sonra gelen ikinci kişidir. Günümüzde eskisi kadar akordeon icracısı kadının olmaması bu durumu daha da ileri seviyelere çıkarmıştır. Günümüzde akordeon çalan kadınlara hayranlıkla bakılmaktadır. Bu doğrultuda toplumun akordeon çalan kadına olan olumlu bakışı nedeniyle kadınlar çalgı seçimlerini rahatlıkla gerçekleştirebilmektedir.

Çerkez kültüründe akordeonu geçmişte ağırlıklı olarak kadınların çaldığı ve günümüzde erkeklerin çaldığı, bu kültürü aktaranların geçmişte tamamen kadınlar olduğu ve günümüzde çoğunlukla erkekler olduğu sonucuna varılmıştır. Kültürel değişimin çalgı kimliğine etkisi olduğu ve bu şekilde akordeonu kadınlardan erkeklerin devraldığı söylenebilir. Günümüzde akordeonun kadın çalgısı olduğu algısı yıkılmaya başlamıştır. Fakat kadınların hala akordeon çalmaya devam ettikleri de görülmektedir. Çalg1 seçimi bağlamında değerlendirildiğinde ise, geçmişte bütün kadınların akordeon çalması ile diğer kadınlarda etkilenerek akordeon seçerken, günümüzde bu kültürün geçmişteki kadar kalmaması ve erkeklerin de akordeon çalmaya başlaması kadınların çalgı seçimlerini de etkilemiştir.

Sonuçlarından yola çıkılarak aşağıda yer alan önerilerde bulunulmuştur;

- Akordeon çalan Çerkez kadınların müzik alanındaki varlığı korunmalı ve devamlılığı sağlanmall,

- Çerkez kadınların Çerkez kültüründeki değişimi durdurmaya yönelik olarak çalgı çalmaları desteklenmeli ve çalgı seçimleri yönlendirilmeli,

- Aileler ve çevre tarafından küçük yaştaki kız çocuklarının akordeon çalma kültürünü sürdürmeleri adına destekleyici yönlendirmelerde bulunmaları sağlanmalı, 
- Geçmişte hemen hemen her kadının akordeon çaldığı ve her Çerkezin evinde akordeon bulunduğu düşünüldüğünde, günümüzde de aynı duruma gelinmesi açısından kadınların ve küçük yaştaki kız çocuklarının akordeon edinmeleri sağlanmalı,

- Çerkez kadınların bu çalgıyı icra edebilmeleri için kurslar açılmalı ve bu kurslara kadınların katılımı sağlanmalı,

- Cinsiyet eşitliğinin kabul gördüğü günümüz yaşamında, yalnızca kadınların değil erkeklerin de bu çalgıyı kullanmaları sağlanmalı,

- Çerkez kültüründeki toplumsal cinsiyet rolleri doğrultusunda gerçekleştirilen çalg1 seçiminin kültürel değişim süreçleri ve sonuçları kayıt altına alınmalıdır.

\section{KAYNAKÇA}

Bayley, J. G. (2000). An investigation of the process by which elementary and junior high school teachers prepare students to choose a musical instrument. Yayınlanmamış doktora tezi, The Ohio State University, Ohia.

Beşiroğlu, Ş. Ş. ve Koçhan, G. (2007). Çeng: bir çalgının toplumsal cinsiyet üzerinden kadın simgesi olarak Kuzey Hint, Timur ve Osmanlı Saraylarındaki görsel malzemeler üzerinden değerlendirilmesi. 38. ICANAS - Uluslararası Asya ve Kuzey Afrika Calışmaları Kongresi. 1, 127-140.

Conway, C. (2000). Gender and musical İnstrument choice: a phenomenological investigation. Bulletin of the Council for Research in Music Education, 146, 1-17.

Erdal, G. (2019). Kocaeli Ketenciler köyü Çerkeslerinde müzik. Online Journal of Music Sciences, 4(2), 198-249.

Ersoy, Ş. (2007). Osmanlıda toplumsal cinsiyet bağlamında köçekler, çengiler. Yayınlanmamış yüksek lisans tezi, İstanbul Teknik Üniversitesi, İstanbul.

Gelibolu, L. ve Tanrıkulu C. (2014). Satışçılarda cinsiyet kimliği: kavramsal bir inceleme. Ç.Ü. Sosyal Bilimler Enstitüsü Dergisi, 23(2), 243-252.

Graham, J. B. (2005). Relationships among instrument choice, instrument transfer, subject sex, and gender-stereotypes in instrumental music. Yayınlanmamış doktora tezi, Indiana University, Indiana.

Gündoğdu, T. (2019). Toplumsal cinsiyet bağlamında Kastamonu'da köçeklik ve köçek müziği. Yayınlanmamış yüksek lisans tezi, Dokuz Eylül Üniversitesi, İzmir.

Hallam, S., Rogers, L. ve Creech, A. (2008). Gender differences in musical instrument choice. International Journal of Music Education, 26(1), 7-19.

Özdemir, M. (2010). Nitel veri analizi: sosyal bilimlerde yöntembilim sorunsalı üzerine bir çalışma. Eskişehir Osmangazi Üniversitesi Sosyal Bilimler Dergisi, 11(1), 323-343. 
Peker, E. H. (2018). Çerkeslerde dü̆̆̈̈n-yemek-giysi kültürü. 18 Aralık 2020 tarihinde https://www.ozelburoistihbarat.com/Content/images/archieve/abhaz-cerkes-cecendosyasi-cerkeslerde-dugun-yemek-giysi-kulturu-35576b88-a11c-4e2b-bb03b3aada622644.pdf adresinden erişildi.

Tok, G. (2018). Çerkes toplumunda kadının yeri (18. ve 19. yüzyıl Rusça kaynaklar). Yayınlanmamış yüksek lisans tezi, Erciyes Üniversitesi, Kayseri.

Üner, S. (2008). Toplumsal cinsiyet eşitliği. Ankara: T.C. Başbakanlık Kadının Statüsü Genel Müdürlüğü Kadına Yönelik Aile İçi Şiddetle Mücadele Projesi.

Vickers, M. E. (2015). The effect of model gender on instrument choice preference of beginning band students. Yayınlanmamış doktora tezi, The Hartt School University of Hartford, Hartford. 